OPEN ACCESS

Edited by:

Cecil Czerkinsky,

University of Nice-Sophia Antipolis,

France

Reviewed by:

Christopher E. Rudd,

University of Cambridge, UK

Kenneth Lee Rosenthal,

McMaster University, Canada

Nichole Klatt,

University of Washington, USA

*Correspondence:

Pushpa Pandiyan

pxp226@case.edu

Specialty section:

This article was submitted

to Mucosal Immunity,

a section of the journal

Frontiers in Immunology

Received: 03 March 2016

Accepted: 26 May 2016

Published: 20 June 2016

Citation:

Pandiyan $P$, Younes $S-A$, Ribeiro $S P$, Talla A, McDonald D, Bhaskaran N, Levine $A D$, Weinberg $A$ and Sekaly RP (2016) Mucosal Regulatory

$T$ Cells and T Helper 17 Cells in HIV-Associated Immune Activation. Front. Immunol. 7:228. doi: 10.3389/fimmu.2016.00228

\section{Mucosal Regulatory T Cells and T Helper 17 Cells in HIV-Associated Immune Activation}

\author{
Pushpa Pandiyan ${ }^{1 *}$, Souheil-Antoine Younes ${ }^{2}$, Susan Pereira Ribeiro ${ }^{3}$, Aarthi Talla ${ }^{3}$, \\ David McDonald ${ }^{4}$, Natarajan Bhaskaran ${ }^{1}$, Alan D. Levine ${ }^{5}$, Aaron Weinberg ${ }^{1}$ and \\ Rafick P. Sekaly ${ }^{3}$
}

\begin{abstract}
'Department of Biological Sciences, School of Dental Medicine, Case Western Reserve University, Cleveland, OH, USA, ${ }^{2}$ Department of Medicine, Division of Infectious Diseases, University Hospitals, Case Western Reserve University, Cleveland, $\mathrm{OH}$, USA, ${ }^{3}$ Department of Pathology, Case Western Reserve University, Cleveland, OH, USA, ${ }^{4}$ Department of Microbiology and Molecular Biology, School of Medicine, Case Western Reserve University, Cleveland, OH, USA, ${ }^{5}$ Department of Pharmacology, School of Medicine, Case Western Reserve University, Cleveland, OH, USA
\end{abstract}

Residual mucosal inflammation along with chronic systemic immune activation is an important feature in individuals infected with human immunodeficiency virus (HIV), and has been linked to a wide range of co-morbidities, including malignancy, opportunistic infections, immunopathology, and cardiovascular complications. Although combined antiretroviral therapy (cART) can reduce plasma viral loads to undetectable levels, reservoirs of virus persist, and increased mortality is associated with immune dysbiosis in mucosal lymphoid tissues. Immune-based therapies are pursued with the goal of improving $\mathrm{CD}^{+}{ }^{+} \mathrm{T}$-cell restoration, as well as reducing chronic immune activation in cART-treated patients. However, the majority of research on immune activation has been derived from analysis of circulating $T$ cells. How immune cell alterations in mucosal tissues contribute to HIV immune dysregulation and the associated risk of non-infectious chronic complications is less studied. Given the significant differences between mucosal $T$ cells and circulating $T$ cells, and the immediate interactions of mucosal $T$ cells with the microbiome, more attention should be devoted to mucosal immune cells and their contribution to systemic immune activation in HIV-infected individuals. Here, we will focus on mucosal immune cells with a specific emphasis on $\mathrm{CD}^{+}{ }^{+} \mathrm{T}$ lymphocytes, such as $T$ helper 17 cells and CD4+Foxp3 ${ }^{+}$regulatory $T$ cells $\left(T_{\text {regs }}\right)$, which play crucial roles in maintaining mucosal barrier integrity and preventing inflammation, respectively. We hypothesize that pro-inflammatory milieu in cART-treated patients with immune activation significantly contributes to enhanced loss of Th17 cells and increased frequency of dysregulated $T_{\text {regs }}$ in the mucosa, which in turn may exacerbate immune dysfunction in HIV-infected patients. We also present initial evidence to support this hypothesis. A better comprehension of how pro-inflammatory milieu impacts these two types of cells in the mucosa will shed light on mucosal immune dysfunction and HIV reservoirs, and lead to novel ways to restore immune functions in $\mathrm{HIV}^{+}$patients.

Keywords: $T_{\text {regs, }}$ Th17, HIV, mucosal immunity, Foxp3 


\section{SYSTEMIC ACTIVATION AND GUT MUCOSAL DYSBIOSIS IN HIV DISEASE}

Human immunodeficiency virus (HIV) associated systemic immune activation constitutes persistent immune dysfunction associated with chronic non-infectious events that include cardiovascular, hepatic, and renal disease, as well as nonAIDS malignancies in cART-treated patients (1-3). Immune reconstitution inflammatory syndrome (IRIS) also comprises of immune abnormalities, although in patients with advanced immunodeficiency and underlying opportunistic infections $(4,5)$. While cART has dramatically changed the fatal course of the epidemic in HIV-infected patients, continuous treatment poses significant challenges in terms of costs and clinical safety. Moreover, despite profound reductions in acute opportunistic infections, persons with treated HIV infection are surviving to experience residual inflammation and HIV-associated chronic end-organ diseases. Antiretroviral therapy also has variable effects in terms of completely reconstituting immune functions. Patients who do not respond to cART completely, i.e., the immunologic non-responders (INR), can maintain much lower peripheral $\mathrm{CD}^{+}{ }^{+} \mathrm{T}$-cell counts (e.g., $<350$ cells/ $\mu \mathrm{l}$ ), despite durable suppression of plasma viral loads to undetectable levels for many years. In patients successfully responding to cART (immune responders; IR; defined variably as CD4 >500 cells $/ \mu \mathrm{l})$, residual disease manifests as milder inflammation and immune senescence. In both settings, the persistence of viral reservoirs in latently infected cells in adipose and lymphoid tissues are evident $(2,3,6-12)$. These reservoirs contribute to rapid rebound of virus replication upon cART termination. Thus, even in the cART era, persistent immune dysregulation predisposes patients to AIDS and non-AIDS clinical events, and also may be linked to persistence of HIV.

Ongoing HIV replication, microbial translocation products, and co-infections have been shown to stimulate the expression of type-1 interferons (IFNs) as well as other pro-inflammatory cytokines in immune cells in blood and in lymphoid tissues $(6,9$, 10, 13-15). These cytokines accelerate residual disease progression by promoting effector $\mathrm{CD} 4^{+}$cell activation and increasing the pool of cells permissive to HIV-1 infection in lymph nodes and mucosal lymphoid tissues (16). Furthermore, loss of Th17 cells and breaches in gut epithelial barriers facilitate increase in systemic levels of bacterial products, prompting persistent immune activation and HIV reactivation $(6,17)$, and independently predicting mortality in HIV patients and simian immune-deficiency (SIV)-infected rhesus macaques $(9,18-20)$. While early cART treatment can reverse to a significant extent the HIV-inflicted gut mucosal injury $(20,21)$, restoration of $\mathrm{CD} 4^{+} \mathrm{T}$ cells in gut lamina propria is minimal to incomplete, when compared to findings in uninfected controls $(15,22-28)$. While these studies begin to further our understanding of gut mucosal dysbiosis $(6,9,17$, 29-35), to date, most of the research on HIV-dependent immune activation has been derived from analysis of circulating $\mathrm{T}$ cells $(21,36-40)$. Further studies are required to examine regional or local effects of inflammation and inflammatory products, as well their site-specific effects on mucosal $\mathrm{CD} 4^{+} \mathrm{T}$ cells and HIV reservoirs. Because mucosal Th17 cells and regulatory $\mathrm{T}$ cells
$\left(\mathrm{T}_{\text {regs }}\right)$ are critical determinants of microbial translocation and inflammation, it is important to study the precise interactions between these cells and various parameters of systemic immune activation.

\section{IMMUNE ACTIVATION CORRELATES TO INCREASED HIV RESERVOIR SIZE}

High level of immune activation is strongly associated with depletion of $\mathrm{CD} 4^{+} \mathrm{T}$ cells and increased proliferation of $\mathrm{CD} 4^{+}$ $\mathrm{T}$ cells $(41,42)$. Expression of the nuclear antigen Ki67 is a recognized marker of cells that have recently been cycling and/or dividing. While higher expression of Ki67 negatively correlates with absolute $\mathrm{CD} 4^{+}$counts, it positively correlates with a larger size of the viral reservoir. While it is unclear, how increased proliferation and HIV reservoir size are linked, these data suggest that increased $\mathrm{T}$-cell proliferation might also provide a mechanism for the maintenance of the HIV reservoir. Increased cycling and higher Ki67 protein expression further correlate with higher expression of PD-1, a marker that can be up-regulated as a result of homeostatic or antigen-induced proliferation, and T-cell exhaustion (43-46). There is a strong association between PD-1 and the immune activation marker Ki67 in $\mathrm{CD}^{+} \mathrm{T}$ cells from cART-treated individuals $(29,42)$. Consistent with these data, reduced PD-1 expression correlates with lower immune activation in HIV-elite controllers, the $\mathrm{HIV}^{+}$infected individuals with immune control of viral loads $(46,47)$. Transcriptomic analyses of $\mathrm{PD}-1^{+}$cells isolated from blood also suggest a significant increase in IFN- $\gamma$ response genes and IL- 6 response genes in INR with higher immune activation, compared to IR with lower immune activation (Figure 1). How PD-1 expression in $\mathrm{CD} 4^{+}$ $\mathrm{T}$ cells contributes to HIV reservoir size and immune activation remains to be investigated. Notably, IL- 6 and IFN- $\gamma$ are found at increased levels in individuals with higher of immune activation $(36,40,48)$. Future studies are required to examine the regulatory aspects of these cytokines in the context of immune activation, $\mathrm{PD}-1$ expression, Th17 and $\mathrm{T}_{\text {reg }}$ cells in $\mathrm{HIV}^{+}$patients. A recent study shows that activated $\mathrm{CD} 4 \mathrm{~T}$ cells co-expressing PD-1, along with CCR7, CXCR5, and CCR6, may represent a highly functional population that is more susceptible to HIV infection and selectively lost in chronic HIV infection (49). Because 80\% of the peripheral $\mathrm{T}$ cells reside in mucosal compartments such as gut $(27,50)$, which also constitutes a rich reservoir, it is critical to understand immune activation effects and the reservoir size, in the context of PD- 1 expression and $\mathrm{CD} 4^{+} \mathrm{T}$-cell homeostasis in the mucosa. Moreover, how immune activation impacts PD-1 expression on Th17 cells and $\mathrm{T}_{\text {regs }}$, and whether these cells harbor HIV reservoirs in the mucosa remain to be investigated.

\section{ALTERATIONS IN MUCOSAL CD4 T-CELL HOMEOSTASIS DURING CART TREATMENT IN HIV-INFECTED PATIENTS}

Intestinal epithelial barrier dysfunction causes an imbalance between the immune system, and mucosal repair and regeneration during primary HIV infection (51-54). Emerging 


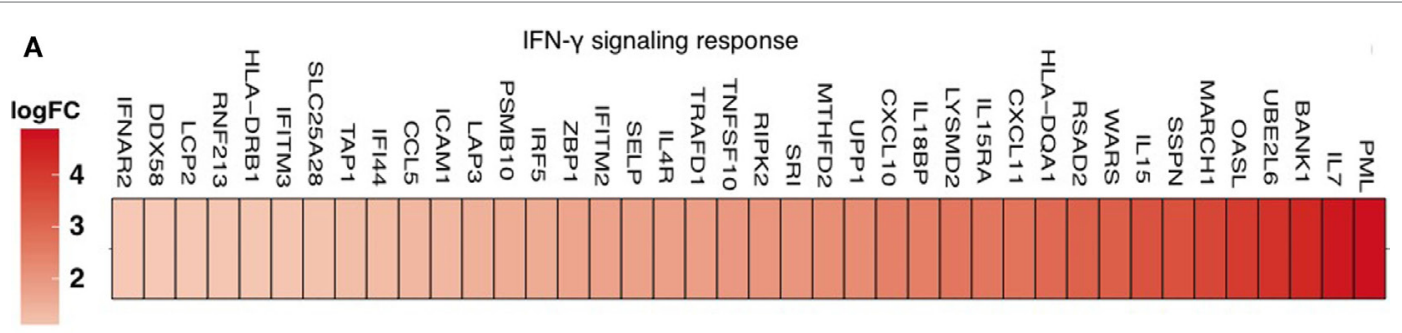

B

IL-6 signaling response

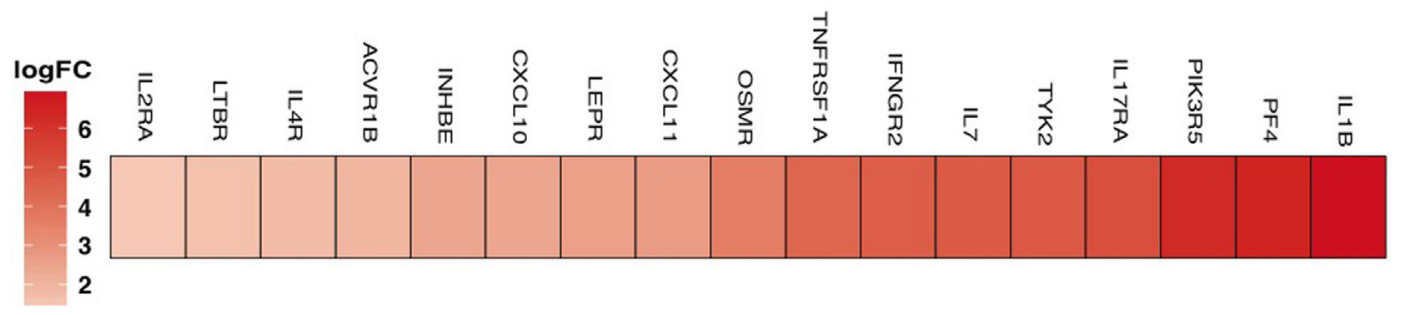

FIGURE 1 | Transcriptome profiling of CD4 ${ }^{+}$T cells in peripheral blood mononuclear cells shows upregulation of interferon- $\gamma$ and IL-6 JAK-STAT responses in CD4+PD-1+ $\mathbf{T}$ cells of INR patients. Enrichment of the IFN- $\gamma$ response pathway (at FDR $=0.14$ ) (above) and IL-6 JAK-STAT3 signaling pathway (below) in $\mathrm{CD} 4^{+} \mathrm{PD}-1^{+}$cells, identified by performing GSEA on the genes differentially expressed comparing INR (higher immune activation) to IR (less immune activation) among HIV/CART-treated patients. (A) Upregulation of the IFN- $\gamma$ response pathway (at $p$-value $<5 \%$ and FDR $<15 \%$ ) and (B) IL-6 JAK-STAT3 signaling pathway in CD4+PD-1+LAG3- $T$ cells, identified by performing GSEA on the genes differentially expressed comparing HIV-infected INR with IR patients. The color scale indicates the log fold-change of the gene being positively expressed and upregulated in the immune failure patients compared to the IR patients.

evidence suggests that the disruption of gut mucosal CD4 ${ }^{+} \mathrm{T}$-cell homeostasis, beyond just the depletion of $\mathrm{CD}^{+} \mathrm{T}$ cells, contributes to persistent systemic $\mathrm{CD} 4^{+}$T-cell activation and HIV pathogenesis in untreated and chronically treated $\mathrm{HIV}^{+}$patients $(9,39,55-57)$. However, $\mathrm{CD}^{+} \mathrm{T}$-cell subsets in the gut and other mucosae are significantly different from $\mathrm{CD} 4^{+} \mathrm{T}$-cell populations in peripheral blood in healthy individuals $(58,59)$. CD $4^{+}$ $\mathrm{T}$ lymphocytes residing in the gut mucosa are predominantly of memory phenotype, and are prone to be more activated due to altered cytokine milieu, interactions with gut microbiota, and constant antigenic exposure $(8,25,26)$. Gut $\mathrm{CD}^{+} \mathrm{T}$ cells also typically express the major HIV co-receptor CCR5, and the $\alpha 4 \beta 7$ integrin that promotes gut homing of $\mathrm{T}$ cells and can also facilitate HIV transmission $(60,61)$. The percentage of infected CD4 ${ }^{+}$ $\mathrm{T}$ cells is much higher in gut mucosa than in circulation as HIV RNA is detectable in $60 \%$ of gut $\mathrm{CD}^{+} \mathrm{T}$ cells. By contrast, HIV RNA is detectable only in $0.01-1 \%$ of peripheral $\mathrm{CD}^{+} \mathrm{T}$ cells during acute infection (23). The underlying mechanisms for these differences are unclear. Unlike peripheral $\mathrm{CD} 4^{+} \mathrm{T}$ cells, the majority of reconstituted gut $\mathrm{CD} 4^{+} \mathrm{T}$ cells is central, transitional, and effector memory $\mathrm{T}$ cells, which are likely in a hyper-inflammatory state secreting cytokines that further stimulate HIV replication in patients treated with cART (27). Given these differences between peripheral and mucosal CD4 ${ }^{+} \mathrm{T}$ cells, and the contribution of CD4 imbalance to mucosal dysbiosis and systemic inflammation, it is important to gain a better understanding on CD4 T-cell homeostasis in the gut and other mucosa.

Most studies demonstrate a partial $\mathrm{CD}^{+} \mathrm{T}$-cell restoration in HIV-infected individuals treated with cART (27). One study examined immune reconstitution in the gut using serial biopsies of rectosigmoid mucosa derived from cART-treated individuals.
It revealed that $\mathrm{HIV}$-mediated $\mathrm{CD} 4^{+} \mathrm{T}$-cell depletion is more significant in immune-effector sites, such as the lamina propria compared to immune-inductive sites, such as the lymphoid tissue. Furthermore, longitudinal examination of individuals with acute HIV infection revealed that while $\mathrm{CD}^{+} \mathrm{T}$-cell reconstitution by cART is complete in immune-inductive sites, it is only partial in mucosal immune-effector sites, compared with healthy HIV-uninfected controls $(24,62)$. While only limited studies have been performed to date in the context of acute and primary infection, evidence suggest that cART initiation early in the course of infection correlates to better gut CD4 T-cell reconstitution. In addition to changes in $\mathrm{CD} 4^{+} \mathrm{T}$-cell numbers within the gut mucosa, altered trafficking of peripheral $\mathrm{CD}^{+} \mathrm{T}$ cells to gut has been proposed as a mechanism contributing to reduced $\mathrm{CD} 4^{+}$ $\mathrm{T}$-cell reconstitution in $\mathrm{HIV}$-infected individuals undergoing treatment $(23,60,61,63)$.

While many of the HIV mucosal studies focus on gut/rectal mucosa, there are only a few studies that have examined $\mathrm{CD} 4^{+}$ $\mathrm{T}$ cells in oral mucosa during SIV/HIV infection $(64,65)$. Although $\mathrm{CD}^{+} \mathrm{T}$ cells are depleted during SIV infection (66), it is not known whether persistent $\mathrm{CD} 4^{+} \mathrm{T}$-cell perturbations post cART treatment contribute to immunopathogenesis in the oral mucosa. Oral opportunistic infections (67) and altered oral microbiome/mycobiome profiles (68-71) are important features of oral inflammation that have been linked to a wide range of pathologies, including periodontitis and oral cancer in $\mathrm{HIV}^{+}$ cART-treated patients (72-75). The oral microbiome comprises over 600 prevalent bacterial taxa and fungi, with distinct subsets predominating in different habitats $(68,70,76-78)$. Similar to commensal dysbiosis and microbial translocation in the gut (79), perturbations in the oral microbiome, or opportunistic 
pathogenic infections, and associated inflammatory products $(67,70,71,80-86)$ may also contribute to oral immune dysregulation and HIV disease progression. While many of the microbial markers in the serum and plasma point to intestinal leakiness, it is not known whether these markers reflect microbial dysbiosis or systemic leakage of microbial products from the oral mucosa. We and others have begun to examine oral mucosa in $\mathrm{HIV}^{+} \mathrm{cART}$ treated patients and in SIV infection, and found alterations in oral epithelial cells and $\mathrm{CD}^{+} \mathrm{T}$ cells $(66,87,88)$. However, the underlying immune mechanisms of $\mathrm{HIV}$-associated immune activation in the context of mucosal $\mathrm{CD} 4^{+} \mathrm{T}$-cell profiles, HIV reservoirs, and immune restoration during chronic HIV disease are still unclear.

\section{Th17 CELL CHANGES IN MUCOSAL IMMUNE PATHOGENESIS}

Th17 cells are CCR6 ${ }^{+}$, ROR- $\gamma \mathrm{t}^{+}$, IL-17-producing CD4+ $\mathrm{T}$ cells that have a pivotal role in maintaining the epithelial barrier in the mucosa $(89,90)$. They play an important role in host defense against fungi and extracellular bacteria, and their importance is evident in mice and Autoimmune Polyendocrinopathy Candidiasis Ectodermal Dystrophy (APECED) patients (90-92). The protective roles of gut mucosal Th17 cells in HIV disease is becoming increasingly clear, and Th17 cell loss has been linked to loss of mucosal epithelial integrity, and results in multiple deleterious sequelae, including microbial translocation and gut inflammation $(20,93-95)$. Incomplete Th17 restoration in the gut despite long-term cART is also linked to persistence of immune activation $(21,23,51,93,96-98)$. Fewer Th17 cells have been observed in the sigmoid colon of HIV-infected INR individuals (CD4 cell count $<350$ cells), compared to HIVuninfected individuals. We also found in colon biopsies that the frequency of ROR $-\gamma \mathrm{t}^{+}$Th17 cells was substantially reduced in cART-treated $\mathrm{HIV}^{+}$patients, compared to uninfected controls (Figure 2A). Previous studies have shown that CCR6 ${ }^{+}$memory and effector Th17 cells in both peripheral blood and inflamed tissues are preferential targets for HIV-1 infection (99). Though underlying mechanisms are unknown, more recent observations show specificities in HIV infection, where Th17 cells specific to Tetanus toxoid and Candida albicans were more permissive to HIV infection, than were CMV specific Th17 cells (99). These results may point to how specific cytokine milieu, or toll-like receptor (TLR) signaling components that differ with each infection, may determine the susceptibility of Th17 cells to HIV infection. While the loss of Th17 cells contributes to gut microbial translocation and systemic inflammation during HIV infection $(20,39,63,65,93,95,100-105)$, the causes for incomplete Th17 cell restoration in the mucosa is unclear. In addition to the local effects on Th17 cells in lamina propria and MALT, perturbations in trafficking of Th17 cells can also alter Th17 homeostasis in the
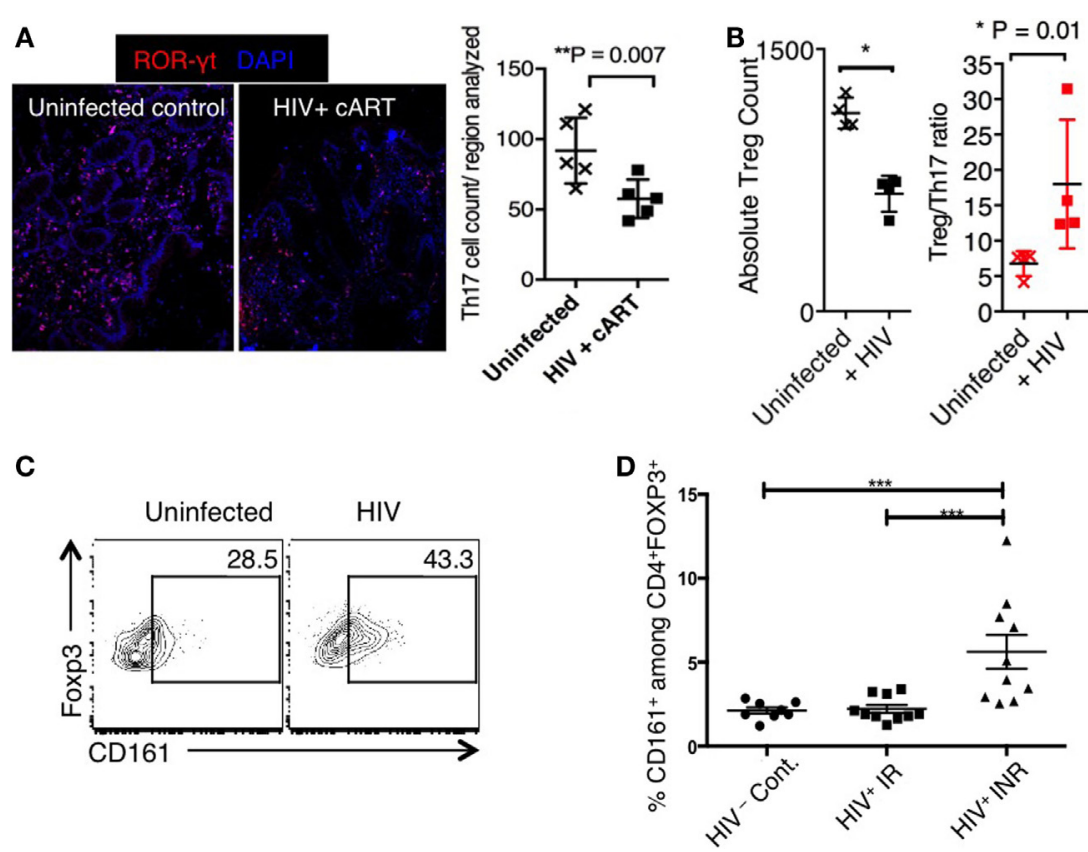

FIGURE 2 | (A) Loss of Th17 cells in biopsies of transverse colon in HIV patients on cART. Frozen blocks of the biopsies were fixed, immunofluorescent stained using $\alpha$-RORyt antibody (red) and 6-diamidino-2-phenylindole (DAPI) (nucleus; blue), and assessed by confocal microscopy. Confocal micrographs (left) and statistics (right). HIV infection induces $\mathrm{T}_{\text {reg }}$ cell loss (B), but CD161 up-regulation in $\mathrm{T}_{\text {regs }}$ (C) in HTC. Three days after in vitro HIV infection, we stimulated the tonsillar cells using $\alpha$-CD3 (T-cell receptor activation) and $\alpha$-CD28 antibodies, and assessed the cells by flow cytometry 3 days later. Representative flow cytometric analyses show Foxp3 ${ }^{+} T_{\text {reg }}$ cell count (left), and $T_{\text {reg }} /$ Th17 ratio (right) (gated on CD4 ${ }^{+}$cells) (B), and CD161 expression in Foxp3 ${ }^{+}$cells (C). (D) CD161 expression on FOXP3 ${ }^{+}$ CD4 T cells in HIV-1 infected IR and INR patients. Shown are the frequencies of CD161+ cells gated on CD3 ${ }^{+}, \mathrm{CD}^{+}$, FOXP3 ${ }^{+} \mathrm{CD}^{+} 27^{-} \mathrm{CD} 25^{+}$in $10 \mathrm{IR}(\mathrm{Median}$ age 47.8, 7M 3F, median CD4 count $910 \mathrm{c} / \mathrm{ll}$ ), $10 \mathrm{INR}$ (Median age 51.9, 7M 3F, median CD4 count $270 \mathrm{c} / \mu \mathrm{l})$, and 8 HIV-uninfected healthy controls (HIV-Cont.). PBMCs were stained with the fluorochrome-conjugated antibodies, acquired by LSRII Fortessa and analyzed by flowjo. Anova test was used for multi-comparison analysis using graphPad Prism software. ${ }^{* \star} P<0.0001$. 
gut mucosa of HIV-infected persons $(57,63)$. For example, in INR patients, a significant increase in $\alpha 4 \beta 7$ positive peripheral Th17 lymphocytes positively correlates with integrated pro-viral DNA in rectum lymphoid cells compared to IR (106). Whether defective migratory capacities and increased HIV infection of gut Th17 cells contribute to impaired reconstitution of Th17 cells in the gut mucosa remain to be studied in different cohorts of $\mathrm{HIV}^{+}$individuals. Specific components of the gut microbiome are known to stimulate the expression of cytokines in innate immune cells, which in turn can affect the generation and expansion of Th17 cells. Because gut microbiome is altered in $\mathrm{HIV}^{+}$individuals $(71,79,107)$, it is likely that it contributes to alterations in Th17 cell numbers and functions. Enhancement of microbiota using probiotics has been shown to modulate mucosal and systemic immune functions and improve GI tract immunity there by mitigating inflammatory sequelae, ultimately improving prognosis in $\mathrm{HIV}^{+}$individuals (108). However, it remains to be seen whether the products of pathogenic microbes from co-infections, opportunistic commensals, differentially affect Th17 cell reconstitution in the gut. In our future studies, we will determine how inflammatory signals, such as microbial TLR ligands, affect Th17 cell viability in the context of their sensitivity to apoptosis and pyroptosis in mucosa and lymphoid tissues (REF).

\section{$T_{\text {reg }}$ CHANGES IN MUCOSA}

$\mathrm{CD}^{+} \mathrm{CD} 25^{+} \mathrm{Foxp}^{+} \mathrm{T}_{\text {regs }}$ are critical for immune balance and effective functioning of the immune system, both in normal and diseased states. They control inflammation by (1) producing immunosuppressive cytokines (109) and (2) inducing cytokine deprivation apoptosis of effector $\mathrm{CD}^{+} \mathrm{T}$ cells (110). They have therapeutic potential in many disease settings, such as infections, cancer, autoimmune diseases, and transplantation (109, 111-113). Severe autoimmunity and inflammation in the absence of $\mathrm{T}_{\text {regs }}$ in immune dysregulation, polyendocrinopathy, enteropathy, and $\mathrm{X}$-linked inheritance (IPEX) patients and during mucosal infections (90-92), highlight the importance of $\mathrm{T}_{\text {regs }}$ in immune homeostasis. Because immune diseases are characterized by increase or decrease in numbers and function of $\mathrm{T}_{\text {regs }}$, there is considerable interest in identifying pathways that control the stability and viability of $\mathrm{T}_{\text {reg }}$ cells. The stability of Foxp $3^{+} \mathrm{T}_{\text {regs }}$ and generation of dysfunctional Foxp $3^{+}$cells at inflammatory disease sites also constitute an active area of immunology research. However, the functional effect of $\mathrm{T}_{\text {regs }}$ on HIV immune pathogenesis is poorly understood (114-116). Recent studies show that $\mathrm{T}_{\text {regs }}$ may not be detrimental to anti-HIV effector responses as previously thought. $\mathrm{T}_{\text {regs }}$ directly inhibit HIV-1 replication in activated T cells (117), and do not suppress antigen specific anti-HIV CD8 responses $(47,118)$. Moreover, $\mathrm{T}_{\text {regs }}$ in circulation strongly correlate with decreased generalized T-cell activation (47, 100-102, 119-129), showing that they may also play critical roles in mitigating immune hyper-activation. On the contrary, some studies suggest that $\mathrm{T}_{\text {regs }}$ have a role in suppressing immune response to HIV and mucosal pathogens (130). Absence of markers to distinguish natural and induced $\mathrm{FOXP}^{+}$cells, functional and dysfunctional $\mathrm{T}_{\text {regs }}$, and limitations in assessing functions of FOXP3 ${ }^{+} \mathrm{T}_{\text {regs }}$ partly play a role in generating these discrepancies $(65,120,130-132)$.
Given that FOXP3 and CD25 are expressed transiently on human effector cells, another important caveat is the sole usage of FOXP3 or CD25 as $\mathrm{T}_{\text {reg }}$ markers in most HIV studies.

Although HIV infection causes depletion of $\mathrm{CD} 4^{+} \mathrm{T}_{\text {regs }}$ leading to their lower absolute cell numbers in blood and gut mucosa (133), FOXP3 ${ }^{+} \mathrm{T}_{\text {regs }}$ are observed in increased proportions in relation to Th17 cells in gut mucosa and oral mucosa during SIV/ HIV infection $(64,65,93,134)$. Given the reciprocal relationship between Th17 cells and $\mathrm{T}_{\text {regs }}, \mathrm{T}_{\text {reg }} / \mathrm{Th} 17$ ratio may be more important than the absolute levels of either one of the subsets independently $(21,94,103,131,132,135-139)$. Consistently, increased $\mathrm{T}_{\text {reg }} /$ Th17 cell ratio correlates to more advanced disease in immune non-responders (CD4 $<350$ cells/ $\mu \mathrm{l})$, viral load, plasma levels of sCD14, sCD163, and IL-1RA (markers of monocyte activation), as well as increased T-cell activation (93, 96, 104, 116, 138, 140-142). However in $\mathrm{HIV}^{+}$patients with elevated levels of immune activation, it is not clear whether the $\mathrm{T}_{\text {regs }}$ are functional or dysfunctional, or natural or induced $(130,132,136,143)$. Our data also show that HIV-infected oral tonsillar cells show an increase in $\mathrm{T}_{\text {reg }} / \mathrm{Th} 17$ ratio (Figure 2B). Increased frequencies of $\mathrm{T}_{\text {regs }}$ can be attributed to indolemine 2,3 dioxygenase (IDO) produced by plasmocytoid DCs, which can promote $\mathrm{T}_{\text {reg }}$ induction during HIV-1 infection (144). We hypothesize that increased proportions of $\mathrm{T}_{\text {regs }}$ may also be attributed to preferential apoptosis or pyroptosis of conventional $\mathrm{CD}^{+} \mathrm{T}$ cells, including Th17 cells in the mucosa. We have previously shown that conventional CD4 T effector cells are highly susceptible to FAS-mediated apoptosis compared to $\mathrm{T}_{\text {regs }}$ in vitro and in vivo (145). In our future studies, we will examine whether differential sensitivities of Th17 cells and $\mathrm{T}_{\text {reg }}$ cells to FAS mediated apoptosis and, or pyroptosis, also contribute to increased $\mathrm{T}_{\text {reg }} / \mathrm{Th} 17$ ratio in mucosa during HIV infection. We will also determine whether $\mathrm{T}_{\text {regs }}$ are just altered in proportions, and if increase in the dysfunctional Foxp $3^{+}$cells contributes to HIV disease progression in the immune activation scenario.

\section{ARE Tregs DYSFUNCTIONAL IN HIV DISEASE?}

Emerging evidence shows that $\mathrm{T}_{\text {regs }}$ become dysfunctional and acquire capacity to produce inflammatory cytokines (146-149), despite the expression of FOXP3, during infections and inflammatory diseases. Such pro-inflammatory cytokine producing polyfunctional FOXP3 ${ }^{+}$cells are shown to have lost their suppressive capacities in the context of certain diseases, such as psoriasis and inflammatory bowel diseases $(146,147,149)$. Our previous findings show that TLR-2 signaling in the context of IL-6 induces pro-inflammatory IL-17A production in $\mathrm{T}_{\text {regs }}$ transiently during an oral mucosal infection. While transient increase of IL-17A producing $\mathrm{T}_{\text {regs }}$ during an acute infection is not detrimental, the persistence of pro-inflammatory cytokine producing $\mathrm{T}_{\text {regs }}$ is strongly associated with inflammation $(146,149,150)$. Similarly during HIV infection, pro-inflammatory cytokines, such as IL-6, commensal bacteria, and their metabolites may affect FOXP3 ${ }^{+}$ cells, induce $\mathrm{T}_{\text {reg }}$ plasticity, and trigger an increase in dysfunctional $\mathrm{T}_{\text {regs }}(146,147,149)$. For example, IL-6 and soluble IL-6 
receptor are observed at increased levels in cART-treated HIV patients, especially in those with a history of immune restoration disease (36). Increased IL-6 levels may contribute to $\mathrm{T}_{\text {reg }}$ dysregulation that may further lead to the vicious loop of exacerbating mucosal and systemic immune dysbiosis in these patients. Another parameter that could affect $\mathrm{T}_{\text {reg }}$ stability is TLR signaling. Excessive TLR signaling in the context of immune activation may also control $\mathrm{T}_{\text {reg }}$ expansion and plasticity during HIV infection. HIV-1 infection is known to modulate TLR responses by altering TLR expression and activation levels, and regulating responses of innate immune cells to TLR stimulation, which may subsequently affect immune activation levels. Given the prevalence of microbial co-infections in $\mathrm{HIV}^{+}$patients [e.g., Mycobacterium tuberculosis (151-153), Porphyromonas gingivalis periodontitis $(67,154)$, and Candida infections $(75,83)]$, increased soluble TLR expression and signaling may also arise from these opportunistic infections. These co-infections can cause an increase in dysregulated $\mathrm{T}_{\text {regs, }}$, and sustain chronic inflammation during HIV-1/SIV infection. Consistent to this hypothesis, the percentage of TLR-2- and TLR-4-expressing $\mathrm{T}_{\text {regs }}$, and the levels of TLR-9 signaling are significantly increased in $\mathrm{HIV}^{+}$patients with $\mathrm{CD} 4$ cell counts $<500$ cells $/ \mathrm{ml}$ in whole blood, correlating with their immune activation $(132,155,156)$. Further studies are required to determine how co-infections and TLR signals contribute to homeostasis and dysfunction of FOXP3 $3^{+} \mathrm{T}_{\text {regs }}$ in the mucosa.

Pro-inflammatory cytokine producing $\mathrm{FOXP}^{+}$cells have been associated with immune dysregulation, and can be identified by a recently described novel marker, CD161 (147, 149). CD161 also defines a Th1/Th17 poly-functional subset of resident memory $\mathrm{T}$ lymphocytes $(157,158)$. In the context of autoimmunity, pathogenic $\mathrm{CD} 161^{+}$memory cells are resistant to

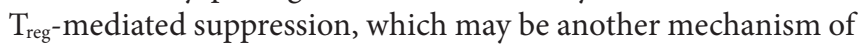
loss of immune homeostasis (159). We observed that HIV infection of tonsillar cells induced CD161 expression in $\mathrm{T}_{\text {regs }}(23 \pm 6$ versus $44 \pm 5 \%, P<0.05$ ) (Figure $2 \mathrm{C}$ ). These results support the possibility that HIV infection may contribute to increased CD161 expression and $\mathrm{T}_{\text {reg }}$ dysfunction in mucosa. Consistent to these data, we also found that a higher proportion of FOXP3+ cells were CD161 positive in INR (with higher immune activation), compared to IR patients (with lower immune activation) in the peripheral blood (Figure 2D). How IL-6 and TLR-ligands enhance CD161 expression, and how CD161 expression contributes to $\mathrm{T}_{\text {reg }}$ dysfunction during HIV infection are areas of intense investigation in our laboratories. In addition to FOXP3+ $\mathrm{T}_{\text {regs }}$, FOXP3 negative T-regulatory type-1 $(\operatorname{Tr} 1)$ cells are major producers of IL-10, and may have a beneficial role in controlling immune activation in early HIV infection (160). However, a recent cross-sectional study in patients with non-progressive HIV-1 infection showed that concentrations of TGF- $\beta 1$ and IL-10 are significantly decreased in their plasma, while IL- $1 \beta$, IL-12p70, and TNF- $\alpha$ are increased, compared to patients with progressive infection (161). Another study also showed that the protein levels of IL-1 $\beta$, IL-6, and IL-10 were significantly lower in plasma of $\mathrm{HIV}$-1-exposed seronegative individuals than HIV-1-infected patients. These data show that disease and infection progression are associated with increased IL-10 and basal pro-inflammatory responses (162). The relationship between
IL-10 and Foxp $3^{+} \mathrm{T}_{\text {regs }}$ remains to be seen. Taken together, since induction, stability, and functions of $\mathrm{FOXP}^{+} \mathrm{T}_{\text {regs }}$ largely depend on the cytokine milieu, detailed studies focusing on $\mathrm{T}_{\text {reg }}$ plasticity and dysfunction in $\mathrm{HIV}^{+}$patients with distinct cytokine will significantly improve our understanding of immune dysregulation in HIV these patients $(109,163,164)$. Such studies will ascertain if the reduction of Treg dysfunction will mitigate HIV-associated immune activation, which in turn would also result in fewer susceptible target $\mathrm{CD}^{+} \mathrm{T}$ cells, and an environment that prevents efficient HIV replication in vivo.

\section{THERAPEUTIC INTERVENTIONS MODULATING Th17 CELLS AND $T_{\text {regs }}$}

Despite the development and optimization of cART that successfully suppresses HIV replication in majority of $\mathrm{HIV}^{+}$patients, a treatment that can cure HIV disease is not yet available. It is unlikely that one single approach will lead to a cure for AIDS. The interaction between HIV and CD $4^{+}$T cells is complex and involves contrasting effects with respect to virus replication (165). On the one hand, $\mathrm{CD}^{+} \mathrm{T}$ cells serve as mediators of antiviral immune responses. It has also been reported that depletion of $\mathrm{CD}^{+} \mathrm{T}$ cells prior to SIV infection in rhesus macaques in fact is associated with higher viral loads, expansion of pro-inflammatory monocytes, and massive activation and infection of macrophages and microglia that appear to be the predominant population of productively infected cells (141). These data highlight the protective roles of $\mathrm{CD}^{+} \mathrm{T}$ cells in modulating inflammation and reducing the viral burden. On the other, proliferating $\mathrm{CD}^{+} \mathrm{T}$ cells are main targets for infection and viral replication. Residual inflammation promotes HIV reservoir persistence by triggering the infection of susceptible cells, and both these processes are inextricably interrelated in a vicious cycle. Therefore, therapies should be targeted to reduce immune activation and inflammation and HIV persistence, as well as enhancing antiviral functions. A previous study has shown that interleukin-21 (IL-21) treatment restores not only the Th17 cells in the gut mucosa, but also dramatically reduces immune dysfunction in rhesus macaques $(104,141,142)$. IL-2 had been employed as a cART adjuvant in phase III clinical trials, but did not restore gut mucosal CD4 ${ }^{+} \mathrm{T}$ cells (166), failing to confer any clinical benefit. Despite successful $\mathrm{CD}^{+}{ }^{+} \mathrm{T}$-cell expansion in peripheral blood, IL- 2 also expanded $\mathrm{T}_{\text {reg }}$ like CD $25^{+}$ cells, increased the levels of IL- 6 and D-dimer, inflammation, and activation of the coagulation cascade $(167,168)$. Whether the expanded $\mathrm{T}_{\text {reg }}$-like cells were $\mathrm{FOXP}^{+}$, or were dysfunctional, was not assessed in those studies. Recombinant human IL-7 (r-hIL-7) has emerged as another candidate immune-based therapy that could succeed in expanding $\mathrm{T}$ cells and inducing the expression of gut homing receptor $\alpha 4 \beta 7$, without expanding $\mathrm{T}_{\text {reg }}$ cells and induction of pro-inflammatory cytokines during administration $(57,169)$. Phase I studies have demonstrated the effect of r-hIL-7 on expansion of $\mathrm{T}$ cells $(57,170)$ and suppressing colonic and systemic inflammation in chronic HIV infection. While IL-7 is a gamma-chain cytokine that could promote $\mathrm{T}_{\text {reg }}$ survival (171), the direct impact of $\mathrm{r}$-hIL-7 treatment on Th17 cells and $\mathrm{T}_{\text {regs }}$ have not been addressed to date in $\mathrm{HIV}^{+}$patients. 


\section{CONCLUSION}

Residual inflammation can be treated by finding synergies between different approaches that are aimed to restore mucosal Th17 cells, and reversing $\mathrm{T}_{\text {reg }}$ dysfunctions in $\mathrm{HIV}^{+}$patients. Given the (1) significant differences between mucosal $\mathrm{T}$ cells and circulating $\mathrm{T}$ cells, (2) immediate interactions of mucosal T cells with the microbiome, (3) gut microbial dysbiosis in $\mathrm{HIV}^{+}$patients, (4) the ability of Th17 cells to maintain mucosal barrier integrity, and a pronounced loss of Th17 cells in $\mathrm{HIV}^{+}$patients, and (5) ability of $\mathrm{T}_{\text {regs }}$ to control immune activation, and the possibilities for them to become dysfunctional in $\mathrm{HIV}^{+}$patients, more research should be devoted to mucosal Th17 cells and $\mathrm{T}_{\text {regs }}$, and their contribution to systemic immune activation in HIV-infected individuals. A better comprehension of these cells will shed light on HIV-mediated mucosal immune dysfunction, and possible new interventional strategies to restore their functions. Because we hypothesize and present in vitro data showing that HIV infection in the context of inflammatory milieu may contribute to dysregulation of these two lymphocyte subsets in the mucosa (Figures 2 and 3), we believe that anti-inflammatory therapeutic strategies increasing protective Th17 cells in the mucosa should be employed as a part of synergistic approach to cure HIV disease.

\section{METHODS}

\section{Human Tonsillar Cultures}

We obtained tonsils from the discarded tissues from HIV-negative patients who undergo tonsillectomy surgery at University
Hospitals/Case Western Reserve University (Age $=8-16$ ) and infected the bulk human tonsillar cultures (HTC) with replication-competent HIV-1 NLAD8-GFP virus stocks (30 ng p24/10 cells) that were generated by transfecting HEK293T cells with pro-viral DNA. NLAD8-GFP was derived from NL43-GFPIRES-Nef (172) by replacing the CXCR4-tropic envelope with CCR5-tropic AD8 envelope. The resulting construct expresses GFP and Nef on a bi-cistronic mRNA $(173,174)$.

\section{Study Cohort and Design}

This study included $17 \mathrm{HIV}$-infected subjects on c-ART for 2 years or greater. The individuals were categorized into two groups - 10 IR who had high CD4 ${ }^{+}$T-cell counts $\left(\mathrm{CD} 4>500\right.$ cells $\left./ \mathrm{mm}^{3}\right)$ and 7 INR who had low $\mathrm{CD}^{+} \mathrm{T}$ cells despite viral suppression (CD4 $>350$ cells $/ \mathrm{mm}^{3}$ ). CD4 ${ }^{+} \mathrm{T}$ cells from these subjects were sorted for cell surface expression of $\mathrm{CD}^{+}, \mathrm{CD}^{+}, \mathrm{CD} 45 \mathrm{RO}^{+}, \mathrm{CD}_{4} 5 \mathrm{RA}^{-}$, and PD- 1 in the absence of LAG3, characterized as PD- $1^{+} \mathrm{LAG}^{-}$cells. One thousand cells were sorted for Illumina RNA-Sequencing.

\section{RNA-Seq Pre-Processing}

Pre-processing of the sequencing data was performed by integrating open source tools and R-Bioconductor packages. The raw reads were trimmed off any adaptor sequence contaminants using Trimmomatic 0.32 , followed by mapping trimmed reads onto the Ensembl version of the Human Genome (Grch38) using the STAR 2.4.0f1 aligner. The transcript counts were then estimated by using HTSeq. The transcript expression was then normalized by trimmed mean of M-values (TMM). Any outlier samples based on abnormalities in gene expression were removed.

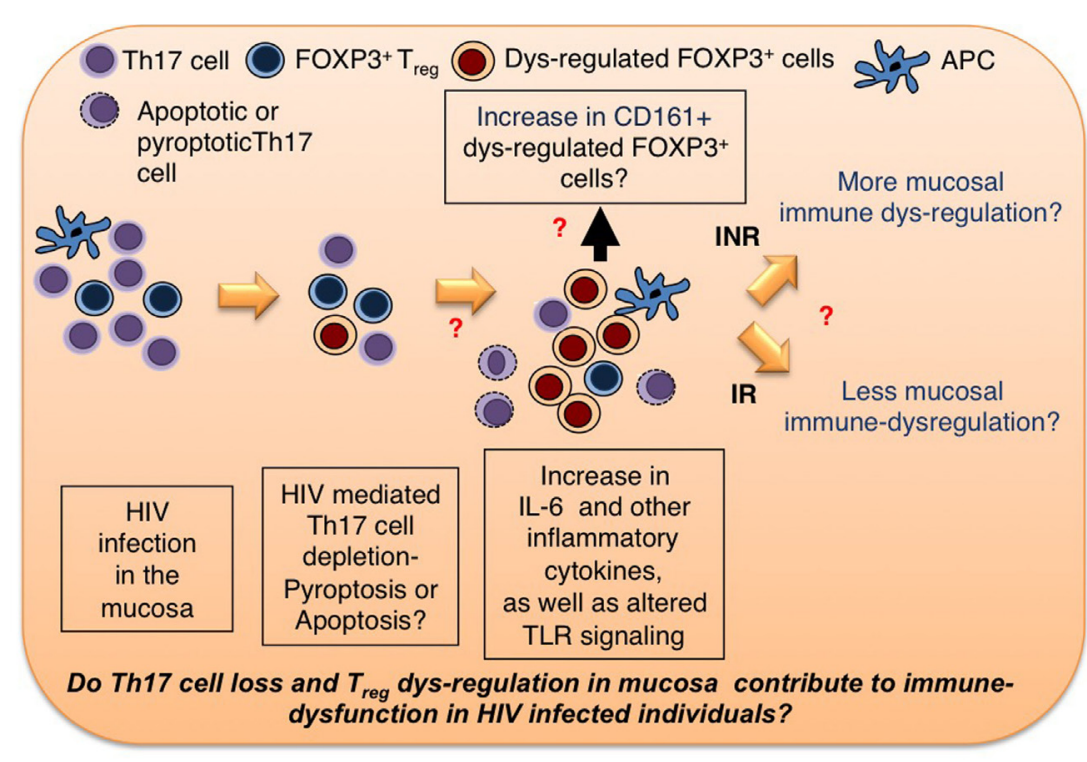

FIGURE 3 | Th17 cell and $\mathbf{T}_{\text {reg }}$ homeostasis in mucosa. HIV infection leads to cellular loss of Th17 cells and $T_{\text {regs }}$ in mucosa. The questions that need to be addressed are as follows: (1) Do inflammatory cytokines and perturbations in TLR signaling contribute to increase in dysregulated FOXP3 ${ }^{+}$cells (Tregs?)? If so, how? What are the markers of dysregulated $T_{\text {regs }}$ ? (2) Does $T_{\text {reg }}$ dysregulation contribute to persistent immune dysfunction in INR HIV+ patients? We hypothesize that therapeutic strategies reducing dysfunctional $T_{\text {regs }}$ and increasing protective Th17 cells in the mucosa should be employed as a part of synergistic approach to cure HIV disease. 


\section{Transcriptomic Profiling of RNA-Seq Data}

The differences in gene expression profiles comparing INR to IR in the $\mathrm{CD}^{+} \mathrm{PD}-1^{+} \mathrm{LAG}^{-} \mathrm{T}$ cells was determined by fitting a generalized linear model (GLM) for every transcript expression. The transcript expression was used as the dependent variable and the groups of interest as the independent variable. Differentially expressed genes were identified by using a likelihood ratio test to test if the fold changes are different from 0. Pathways enriched among the differential expressed genes were identified by Gene Set Enrichment Analysis (GSEA) pre-ranked by the decreasing order of $-\log 10(p$-value $) \times \operatorname{sign}($ log-fold change $)$ of the gene with a 1000 permutations. The pathway database used was the Hallmark genes (version 5.0) from the Molecular Signatures DataBase (MSigDB). The obtained $p$-values were corrected for multiple comparisons by the Benjamini and Hochberg method.

\section{CONSENT PROCEDURE}

The study staff will talk with the volunteers about the consent information. Study participants are free to ask questions about this study at any time. If they agree to take part in this study, they will be asked to sign the consent form. They will get a copy to keep. Before they learn about the study, it is important that they know the following:

- Their participation is entirely voluntary.

- They may decide not to take part in or to withdraw from the study at any time without losing the benefits of their routine medical care.

\section{REFERENCES}

1. Kelley CF, Kitchen CM, Hunt PW, Rodriguez B, Hecht FM, Kitahata M, et al. Incomplete peripheral CD4+ cell count restoration in HIV-infected patients receiving long-term antiretroviral treatment. Clin Infect Dis (2009) 48:787-94. doi:10.1086/597093

2. Guihot A, Bourgarit A, Carcelain G, Autran B. Immune reconstitution after a decade of combined antiretroviral therapies for human immunodeficiency virus. Trends Immunol (2011) 32:131-7. doi:10.1016/j.it.2010.12.002

3. Sauce D, Larsen M, Fastenackels S, Pauchard M, Ait-Mohand H, Schneider L, et al. HIV disease progression despite suppression of viral replication is associated with exhaustion of lymphopoiesis. Blood (2011) 117:5142-51. doi:10.1182/blood-2011-01-331306

4. Ramirez-Amador V, Nittayananta W, Magalhaes M, Flint SR, Peters BS, Tappuni AR. Clinical markers of immunodeficiency and mechanism of immune reconstitution inflammatory syndrome and highly active antiretroviral therapy on HIV: workshop 3A. Adv Dent Res (2011) 23:165-71. doi:10.1177/0022034511400080

5. Tappuni AR. Immune reconstitution inflammatory syndrome. Adv Dent Res (2011) 23:90-6. doi:10.1177/0022034511399915

6. Brenchley JM, Price DA, Douek DC. HIV disease: fallout from a mucosal catastrophe? Nat Immunol (2006) 7:235-9. doi:10.1038/ni1316

7. Lerner P, Guadalupe M, Donovan R, Hung J, Flamm J, Prindiville T, et al. The gut mucosal viral reservoir in HIV-infected patients is not the major source of rebound plasma viremia following interruption of highly active antiretroviral therapy. J Virol (2011) 85:4772-82. doi:10.1128/JVI.02409-10

8. Catalfamo M, Le Saout C, Lane HC. The role of cytokines in the pathogenesis and treatment of HIV infection. Cytokine Growth Factor Rev (2012) 23:207-14. doi:10.1016/j.cytogfr.2012.05.007
Discarded tonsils are collected from minors involved in tonsillectomy surgery. Otherwise minors are not directly involved in the study.

\section{ETHICS STATEMENT}

Human cells were obtained from PBMC under approved protocols, reviewed and approved by the University Hospitals Case Medical Center Institutional review boards.

\section{AUTHOR CONTRIBUTIONS}

PP designed the study, performed experiments, analyzed data and wrote the manuscript; SAY, NB, DM, AT and SPR performed experiments; ADL helped with providing gut biopsies and contributed to discussions, RPS contributed to discussions and edited the manuscript, and AW edited the manuscript.

\section{ACKNOWLEDGMENTS}

Human cells were obtained from PBMC under approved PP was supported by departmental startup funding from School of Dental Medicine. We thank Dr. Michael Lederman for reading the manuscript critically. We thank Case Comprehensive Cancer canter flow cytometry core facility for assisting in FACS cell purification, and CFAR flow cytometry core for granting access to its flow cytometer analyzers.

9. Brenchley JM. Mucosal immunity in human and simian immunodeficiency lentivirus infections. Mucosal Immunol (2013) 6:657-65. doi:10.1038/mi.2013.15

10. Klatt NR, Funderburg NT, Brenchley JM. Microbial translocation, immune activation, and HIV disease. Trends Microbiol (2013) 21:6-13. doi:10.1016/j. tim.2012.09.001

11. Damouche A, Lazure T, Avettand-Fenoel V, Huot N, Dejucq-Rainsford N, Satie AP, et al. Adipose tissue is a neglected viral reservoir and an inflammatory site during chronic HIV and SIV infection. PLoS Pathog (2015) 11:e1005153. doi:10.1371/journal.ppat.1005153

12. Lorenzo-Redondo R, Fryer HR, Bedford T, Kim EY, Archer J, Kosakovsky Pond SL, et al. Persistent HIV-1 replication maintains the tissue reservoir during therapy. Nature (2016) 530:51-6. doi:10.1038/nature16933

13. Deeks SG, Kitchen CM, Liu L, Guo H, Gascon R, Narvaez AB, et al. Immune activation set point during early HIV infection predicts subsequent CD4+ T-cell changes independent of viral load. Blood (2004) 104:942-7. doi:10.1182/blood-2003-09-3333

14. Hunt PW. Role of immune activation in HIV pathogenesis. Curr HIV/AIDS Rep (2007) 4:42-7. doi:10.1007/s11904-007-0007-8

15. Klatt NR, Chomont N, Douek DC, Deeks SG. Immune activation and HIV persistence: implications for curative approaches to HIV infection. Immunol Rev (2013) 254:326-42. doi:10.1111/imr.12065

16. Tincati C, Biasin M, Bandera A, Violin M, Marchetti G, Piacentini L, et al. Early initiation of highly active antiretroviral therapy fails to reverse immunovirological abnormalities in gut-associated lymphoid tissue induced by acute HIV infection. Antivir Ther (2009) 14:321-30.

17. Brenchley JM, Price DA, Schacker TW, Asher TE, Silvestri G, Rao S, et al. Microbial translocation is a cause of systemic immune activation in chronic HIV infection. Nat Med (2006) 12:1365-71. doi:10.1038/ $\mathrm{nm} 1511$ 
18. Sandler NG, Wand H, Roque A, Law M, Nason MC, Nixon DE, et al. Plasma levels of soluble CD14 independently predict mortality in HIV infection. J Infect Dis (2011) 203:780-90. doi:10.1093/infdis/jiq118

19. Bastard JP, Soulie C, Fellahi S, Haim-Boukobza S, Simon A, Katlama C, et al. Circulating interleukin-6 levels correlate with residual HIV viraemia and markers of immune dysfunction in treatment-controlled HIV-infected patients. Antivir Ther (2012) 17:915-9. doi:10.3851/IMP2093

20. Schuetz A, Deleage C, Sereti I, Rerknimitr R, Phanuphak N, Phuang-Ngern Y, et al. Initiation of ART during early acute HIV infection preserves mucosal Th17 function and reverses HIV-related immune activation. PLoS Pathog (2014) 10:e1004543. doi:10.1371/journal.ppat.1004543

21. Macal M, Sankaran S, Chun TW, Reay E, Flamm J, Prindiville TJ, et al. Effective CD4+ T-cell restoration in gut-associated lymphoid tissue of HIV-infected patients is associated with enhanced Th17 cells and polyfunctional HIV-specific T-cell responses. Mucosal Immunol (2008) 1:475-88. doi:10.1038/mi.2008.35

22. Schacker TW, Nguyen PL, Martinez E, Reilly C, Gatell JM, Horban A, et al. Persistent abnormalities in lymphoid tissues of human immunodeficiency virus-infected patients successfully treated with highly active antiretroviral therapy. J Infect Dis (2002) 186:1092-7. doi:10.1086/343802

23. Guadalupe M, Sankaran S, George MD, Reay E, Verhoeven D, Shacklett BL, et al. Viral suppression and immune restoration in the gastrointestinal mucosa of human immunodeficiency virus type 1-infected patients initiating therapy during primary or chronic infection. J Virol (2006) 80:8236-47. doi:10.1128/JVI.00120-06

24. Mehandru S, Poles MA, Tenner-Racz K, Jean-Pierre P, Manuelli V, Lopez P, et al. Lack of mucosal immune reconstitution during prolonged treatment of acute and early HIV-1 infection. PLoS Med (2006) 3:e484. doi:10.1371/ journal.pmed.0030484

25. Ciccone EJ, Read SW, Mannon PJ, Yao MD, Hodge JN, Dewar R, et al. Cycling of gut mucosal CD4+ T cells decreases after prolonged anti-retroviral therapy and is associated with plasma LPS levels. Mucosal Immunol (2010) 3:172-81. doi:10.1038/mi.2009.129

26. Ciccone EJ, Greenwald JH, Lee PI, Biancotto A, Read SW, Yao MA, et al. CD4+ T cells, including Th17 and cycling subsets, are intact in the gut mucosa of HIV-1-infected long-term nonprogressors. J Virol (2011) 85:5880-8. doi:10.1128/JVI.02643-10

27. Costiniuk CT, Angel JB. Human immunodeficiency virus and the gastrointestinal immune system: does highly active antiretroviral therapy restore gut immunity? Mucosal Immunol (2012) 5:596-604. doi:10.1038/mi.2012.82

28. Cassol E, Malfeld S, Mahasha P, Bond R, Slavik T, Seebregts C, et al. Impaired $\mathrm{CD} 4+\mathrm{T}$-cell restoration in the small versus large intestine of HIV-1-positive South Africans receiving combination antiretroviral therapy. J Infect Dis (2013) 208:1113-22. doi:10.1093/infdis/jit249

29. Lederman MM, Calabrese L, Funderburg NT, Clagett B, Medvik K, Bonilla H, et al. Immunologic failure despite suppressive antiretroviral therapy is related to activation and turnover of memory CD4 cells. J Infect Dis (2011) 204:1217-26. doi:10.1093/infdis/jir507

30. Shive CL, Biancotto A, Funderburg NT, Pilch-Cooper HA, Valdez H, Margolis L, et al. HIV-1 is not a major driver of increased plasma IL-6 levels in chronic HIV-1 disease. J Acquir Immune Defic Syndr (2012) 61:145-52. doi:10.1097/QAI.0b013e31825ddbbf

31. Jiang W, Younes SA, Funderburg NT, Mudd JC, Espinosa E, Davenport MP, et al. Cycling memory CD4+ T cells in HIV disease have a diverse $\mathrm{T}$ cell receptor repertoire and a phenotype consistent with bystander activation. J Virol (2014) 88:5369-80. doi:10.1128/JVI.00017-14

32. Mudd JC, Lederman MM. CD8 T cell persistence in treated HIV infection. Curr Opin HIV AIDS (2014) 9:500-5. doi:10.1097/COH.0000000000000086

33. Shive CL, Mudd JC, Funderburg NT, Sieg SF, Kyi B, Bazdar DA, et al. Inflammatory cytokines drive CD4+ T-cell cycling and impaired responsiveness to interleukin 7: implications for immune failure in HIV disease. J Infect Dis (2014) 210:619-29. doi:10.1093/infdis/jiu125

34. Shive CL, Jiang W, Anthony DD, Lederman MM. Soluble CD14 is a nonspecific marker of monocyte activation. AIDS (2015) 29:1263-5. doi:10.1097/QAD.0000000000000735

35. Hunt PW, Sinclair E, Rodriguez B, Shive C, Clagett B, Funderburg N, et al. Gut epithelial barrier dysfunction and innate immune activation predict mortality in treated HIV infection. J Infect Dis (2014) 210:1228-38. doi:10.1093/infdis/jiu238
36. Stone SF, Price P, Keane NM, Murray RJ, French MA. Levels of IL-6 and soluble IL-6 receptor are increased in HIV patients with a history of immune restoration disease after HAART. HIV Med (2002) 3:21-7. doi:10.1046/j.1464-2662.2001.00096.x

37. Cecchinato V, Trindade CJ, Laurence A, Heraud JM, Brenchley JM, Ferrari MG, et al. Altered balance between Th17 and Th1 cells at mucosal sites predicts AIDS progression in simian immunodeficiency virus-infected macaques. Mucosal Immunol (2008) 1:279-88. doi:10.1038/mi.2008.14

38. Villacres MC, Kono N, Mack WJ, Nowicki MJ, Anastos K, Augenbraun M, et al. Interleukin 10 responses are associated with sustained CD4 T-cell counts in treated HIV infection. J Infect Dis (2012) 206:780-9. doi:10.1093/ infdis/jis380

39. Kim CJ, McKinnon LR, Kovacs C, Kandel G, Huibner S, Chege D, et al. Mucosal Th17 cell function is altered during HIV infection and is an independent predictor of systemic immune activation. J Immunol (2013) 191:2164-73. doi:10.4049/jimmunol.1300829

40. Voigt RM, Keshavarzian A, Losurdo J, Swanson G, Siewe B, Forsyth CB, et al. $\mathrm{HIV}$-associated mucosal gene expression: region-specific alterations. AIDS (2015) 29:537-46. doi:10.1097/QAD.0000000000000569

41. Sousa AE, Carneiro J, Meier-Schellersheim M, Grossman Z, Victorino RM. CD4 $\mathrm{T}$ cell depletion is linked directly to immune activation in the pathogenesis of HIV-1 and HIV-2 but only indirectly to the viral load. J Immunol (2002) 169:3400-6. doi:10.4049/jimmunol.169.6.3400

42. Chomont N, El-Far M, Ancuta P, Trautmann L, Procopio FA, Yassine-Diab B, et al. HIV reservoir size and persistence are driven by $\mathrm{T}$ cell survival and homeostatic proliferation. Nat Med (2009) 15:893-900. doi:10.1038/nm.1972

43. Lin SJ, Peacock CD, Bahl K, Welsh RM. Programmed death-1 (PD-1) defines a transient and dysfunctional oligoclonal $\mathrm{T}$ cell population in acute homeostatic proliferation. JExp Med (2007) 204:2321-33. doi:10.1084/ jem. 20062150

44. Hokey DA, Johnson FB, Smith J, Weber JL, Yan J, Hirao L, et al. Activation drives PD-1 expression during vaccine-specific proliferation and following lentiviral infection in macaques. Eur JImmunol (2008) 38:1435-45. doi:10.1002/eji.200737857

45. Kinter AL, Godbout EJ, McNally JP, Sereti I, Roby GA, O’Shea MA, et al. The common gamma-chain cytokines IL-2, IL-7, IL-15, and IL-21 induce the expression of programmed death-1 and its ligands. J Immunol (2008) 181:6738-46. doi:10.4049/jimmunol.181.10.6738

46. Bansal A, Sterrett S, Erdmann N, Westfall AO, Dionne-Odom J, Overton ET, et al. Normal T-cell activation in elite controllers with preserved CD4+ T-cell counts. AIDS (2015) 29:2245-54. doi:10.1097/QAD.0000000000000860

47. Chase AJ, Yang HC, Zhang H, Blankson JN, Siliciano RF. Preservation of FoxP3+ regulatory $\mathrm{T}$ cells in the peripheral blood of human immunodeficiency virus type 1 -infected elite suppressors correlates with low CD4+ T-cell activation. J Virol (2008) 82:8307-15. doi:10.1128/JVI.00520-08

48. Grant PM, Komarow L, Lederman MM, Pahwa S, Zolopa AR, Andersen J, et al. Elevated interleukin 8 and T-helper 1 and T-helper 17 cytokine levels prior to antiretroviral therapy in participants who developed immune reconstitution inflammatory syndrome during ACTG A5164. J Infect Dis (2012) 206:1715-23. doi:10.1093/infdis/jis604

49. Paris RM, Petrovas C, Ferrando-Martinez S, Moysi E, Boswell KL, Archer E, et al. Selective loss of early differentiated, highly functional PD1high CD4 T cells with HIV progression. PLoS One (2015) 10:e0144767. doi:10.1371/ journal.pone.0144767

50. Mowat AM, Viney JL. The anatomical basis of intestinal immunity. Immunol $\operatorname{Rev}(1997)$ 156:145-66. doi:10.1111/j.1600-065X.1997.tb00966.x

51. Sankaran S, George MD, Reay E, Guadalupe M, Flamm J, Prindiville T, et al. Rapid onset of intestinal epithelial barrier dysfunction in primary human immunodeficiency virus infection is driven by an imbalance between immune response and mucosal repair and regeneration. J Virol (2008) 82:538-45. doi:10.1128/JVI.01449-07

52. Epple HJ, Allers K, Troger H, Kuhl A, Erben U, Fromm M, et al. Acute HIV infection induces mucosal infiltration with CD4+ and CD8+ T cells, epithelial apoptosis, and a mucosal barrier defect. Gastroenterology (2010) 139:1289-300. doi:10.1053/j.gastro.2010.06.065

53. Estes JD, Harris LD, Klatt NR, Tabb B, Pittaluga S, Paiardini M, et al. Damaged intestinal epithelial integrity linked to microbial translocation in pathogenic simian immunodeficiency virus infections. PLoS Pathog (2010) 6:e1001052. doi:10.1371/journal.ppat.1001052 
54. Karantza V. Keratins in health and cancer: more than mere epithelial cell markers. Oncogene (2011) 30:127-38. doi:10.1038/onc.2010.456

55. Gordon SN, Klatt NR, Bosinger SE, Brenchley JM, Milush JM, Engram JC, et al. Severe depletion of mucosal CD4+ T cells in AIDS-free simian immunodeficiency virus-infected sooty mangabeys. J Immunol (2007) 179:3026-34. doi:10.4049/jimmunol.179.5.3026

56. Gordon SN, Cervasi B, Odorizzi P, Silverman R, Aberra F, Ginsberg G, et al. Disruption of intestinal CD4+ T cell homeostasis is a key marker of systemic CD4+ T cell activation in HIV-infected individuals. J Immunol (2010) 185:5169-79. doi:10.4049/jimmunol.1001801

57. Sereti I, Estes JD, Thompson WL, Morcock DR, Fischl MA, Croughs T, et al. Decreases in colonic and systemic inflammation in chronic HIV infection after IL-7 administration. PLoS Pathog (2014) 10:e1003890. doi:10.1371/ journal.ppat. 1003890

58. Shan L, Siliciano RF. Unraveling the relationship between microbial translocation and systemic immune activation in HIV infection. J Clin Invest (2014) 124:2368-71. doi:10.1172/JCI75799

59. Somsouk M, Estes JD, Deleage C, Dunham RM, Albright R, Inadomi JM, et al. Gut epithelial barrier and systemic inflammation during chronic HIV infection. AIDS (2015) 29:43-51. doi:10.1097/ QAD.0000000000000511

60. Arthos J, Cicala C, Martinelli E, Macleod K, Van Ryk D, Wei D, et al. HIV-1 envelope protein binds to and signals through integrin alpha4beta7, the gut mucosal homing receptor for peripheral T cells. Nat Immunol (2008) 9:301-9. doi:10.1038/ni1566

61. Wacleche VS, Chomont N, Gosselin A, Monteiro P, Goupil M, Kared H, et al. The colocalization potential of HIV-specific CD8+ and CD4+ T-cells is mediated by integrin beta7 but not CCR6 and regulated by retinoic acid. PLoS One (2012) 7:e32964. doi:10.1371/journal. pone. 0032964

62. Mehandru S, Poles MA, Tenner-Racz K, Horowitz A, Hurley A, Hogan C, et al. Primary HIV-1 infection is associated with preferential depletion of CD4+ T lymphocytes from effector sites in the gastrointestinal tract. J Exp Med (2004) 200:761-70. doi:10.1084/jem.20041196

63. Mavigner M, Cazabat M, Dubois M, L'Faqihi FE, Requena M, Pasquier C, et al. Altered $\mathrm{CD} 4+\mathrm{T}$ cell homing to the gut impairs mucosal immune reconstitution in treated HIV-infected individuals. J Clin Invest (2012) 122:62-9. doi:10.1172/JCI59011

64. Andersson J, Fehniger TE, Patterson BK, Pottage J, Agnoli M, Jones P, et al. Early reduction of immune activation in lymphoid tissue following highly active HIV therapy. AIDS (1998) 12:F123-9. doi:10.1097/00002030-199811000-00004

65. Nilsson J, Boasso A, Velilla PA, Zhang R, Vaccari M, Franchini G, et al. HIV-1driven regulatory T-cell accumulation in lymphoid tissues is associated with disease progression in HIV/AIDS. Blood (2006) 108:3808-17. doi:10.1182/ blood-2006-05-021576

66. George J, Wagner W, Lewis MG, Mattapallil JJ. Significant depletion of CD4(+) T cells occurs in the oral mucosa during simian immunodeficiency virus infection with the infected CD4(+) T cell reservoir continuing to persist in the oral mucosa during antiretroviral therapy. JImmunol Res (2015) 2015:673815. doi:10.1155/2015/673815

67. Gonzalez OA, Li M, Ebersole JL, Huang CB. HIV-1 reactivation induced by the periodontal pathogens Fusobacterium nucleatum and Porphyromonas gingivalis involves toll-like receptor 2 [corrected] and 9 activation in monocytes/ macrophages. Clin Vaccine Immunol (2010) 17:1417-27. doi:10.1128/CVI. 00009-10

68. Aas JA, Paster BJ, Stokes LN, Olsen I, Dewhirst FE. Defining the normal bacterial flora of the oral cavity. J Clin Microbiol (2005) 43:5721-32. doi:10.1128/ JCM.43.11.5721-5732.2005

69. Aas JA, Barbuto SM, Alpagot T, Olsen I, Dewhirst FE, Paster BJ. Subgingival plaque microbiota in HIV positive patients. JClin Periodontol (2007) 34:189-95. doi:10.1111/j.1600-051X.2006.01034.x

70. Ghannoum MA, Jurevic RJ, Mukherjee PK, Cui F, Sikaroodi M, Naqvi A, et al. Characterization of the oral fungal microbiome (mycobiome) in healthy individuals. PLoS Pathog (2010) 6:e1000713. doi:10.1371/journal. ppat. 1000713

71. Mukherjee PK, Chandra J, Retuerto M, Sikaroodi M, Brown RE, Jurevic R, et al. Oral mycobiome analysis of HIV-infected patients: identification of Pichia as an antagonist of opportunistic fungi. PLoS Pathog (2014) 10:e1003996. doi:10.1371/journal.ppat.1003996
72. Robinson PG. The oral manifestations of HIV infection. Int J STD AIDS (1997) 8:668-74. doi:10.1258/0956462971919039

73. Robinson PG, Challacombe SJ, Sheiham A, Zakrzewska JM. Is erythematous candidiasis associated with advanced HIV disease? Oral Dis (1997) 3(Suppl 1): S116-8. doi:10.1111/j.1601-0825.1997.tb00339.x

74. Robinson PG, Sheiham A, Challacombe SJ, Zakrzewska JM. Periodontal health and HIV infection. Oral Dis (1997) 3(Suppl 1):S149-52. doi:10.111 1/j.1601-0825.1997.tb00349.x

75. Patton LL. Oral lesions associated with human immunodeficiency virus disease. Dent Clin North Am (2013) 57:673-98. doi:10.1016/j.cden.2013.07.005

76. Chen T, Yu WH, Izard J, Baranova OV, Lakshmanan A, Dewhirst FE. The human oral microbiome database: a web accessible resource for investigating oral microbe taxonomic and genomic information. Database (Oxford) (2010) 2010:baq013. doi:10.1093/database/baq013

77. Dewhirst FE, Chen T, Izard J, Paster BJ, Tanner AC, Yu WH, et al. The human oral microbiome. J Bacteriol (2010) 192:5002-17. doi:10.1128/JB.00542-10

78. Ahn J, Yang L, Paster BJ, Ganly I, Morris L, Pei Z, et al. Oral microbiome profiles: $16 \mathrm{~S}$ rRNA pyrosequencing and microarray assay comparison. PLoS One (2011) 6:e22788. doi:10.1371/journal.pone.0022788

79. Zevin AS, McKinnon L, Burgener A, Klatt NR. Microbial translocation and microbiome dysbiosis in HIV-associated immune activation. Curr Opin HIV AIDS (2016) 11:182-90. doi:10.1097/COH.0000000000000234

80. Webster-Cyriaque J, Duus K, Cooper C, Duncan M. OralEBV and KSHV infection in HIV. Adv Dent Res (2006) 19:91-5. doi:10.1177/154407370601900118

81. Ferreira S, Noce C, Junior AS, Goncalves L, Torres S, Meeks V, et al. Prevalence of oral manifestations of HIV infection in Rio De Janeiro, Brazil from 1988 to 2004. AIDS Patient Care STDS (2007) 21:724-31. doi:10.1089/apc. 2006.0211

82. Goncalves LS, Soares Ferreira SM, Souza CO, Souto R, Colombo AP. Clinical and microbiological profiles of human immunodeficiency virus (HIV)seropositive Brazilians undergoing highly active antiretroviral therapy and HIV-seronegative Brazilians with chronic periodontitis. J Periodontol (2007) 78:87-96. doi:10.1902/jop.2007.060040

83. Shiboski CH, Patton LL, Webster-Cyriaque JY, Greenspan D, Traboulsi RS, Ghannoum M, et al. The oral HIV/AIDS research alliance: updated case definitions of oral disease endpoints. J Oral Pathol Med (2009) 38:481-8. doi:10.1111/j.1600-0714.2009.00749.x

84. Shiboski CH, Webster-Cyriaque JY, Ghannoum M, Greenspan JS, Dittmer D; Oral HIV/AIDS Research Alliance, Subcommittee of the AIDS Clinical Trial Group. Overview of the oral HIV/AIDS research alliance program. Adv Dent Res (2011) 23:28-33. doi:10.1177/0022034511399084

85. Ghannoum MA, Mukherjee PK, Jurevic RJ, Retuerto M, Brown RE, Sikaroodi M, et al. Metabolomics reveals differential levels of oral metabolites in HIV-infected patients: toward novel diagnostic targets. OMICS (2013) 17:5-15. doi:10.1089/omi.2011.0035

86. Yu X, Shahir AM, Sha J, Feng Z, Eapen B, Nithianantham S, et al. Shortchain fatty acids from periodontal pathogens suppress histone deacetylases, EZH2, and SUV39H1 to promote Kaposi's sarcoma-associated herpesvirus replication. J Virol (2014) 88:4466-79. doi:10.1128/JVI.03326-13

87. Yohannes E, Ghosh SK, Jiang B, McCormick TS, Weinberg A, Hill E, et al. Proteomic signatures of human oral epithelial cells in HIV-infected subjects. PLoS One (2011) 6:e27816. doi:10.1371/journal.pone.0027816

88. Ghosh SK, McCormick TS, Eapen BL, Yohannes E, Chance MR, Weinberg A. Comparison of epigenetic profiles of human oral epithelial cells from HIVpositive (on HAART) and HIV-negative subjects. Epigenetics (2013) 8:703-9. doi:10.4161/epi.25028

89. Weaver CT, Harrington LE, Mangan PR, Gavrieli M, Murphy KM. Th17: an effector CD4 T cell lineage with regulatory T cell ties. Immunity (2006) 24:677-88. doi:10.1016/j.immuni.2006.06.002

90. Pandiyan P, Conti HR, Zheng L, Peterson AC, Mathern DR, HernandezSantos N, et al. CD4(+)CD25(+)Foxp3(+) regulatory $\mathrm{T}$ cells promote Th17 cells in vitro and enhance host resistance in mouse Candida albicans Th17 cell infection model. Immunity (2011) 34:422-34. doi:10.1016/j. immuni.2011.03.002

91. Milner JD, Brenchley JM, Laurence A, Freeman AF, Hill BJ, Elias KM, et al. Impaired $\mathrm{T}(\mathrm{H}) 17$ cell differentiation in subjects with autosomal dominant hyper-IgE syndrome. Nature (2008) 452:773-6. doi:10.1038/nature06764

92. Moraes-Vasconcelos D, Costa-Carvalho BT, Torgerson TR, Ochs HD, Primary immune deficiency disorders presenting as autoimmune diseases: 
IPEX and APECED. J Clin Immunol (2008) 28(Suppl 1):S11-9. doi:10.1007/ s10875-008-9176-5

93. Kanwar B, Favre D, McCune JM. Th17 and regulatory T cells: implications for AIDS pathogenesis. Curr Opin HIV AIDS (2010) 5:151-7. doi:10.1097/ COH.0b013e328335c0c1

94. Hartigan-O'Connor DJ, Hirao LA, McCune JM, Dandekar S. Th17 cells and regulatory T cells in elite control over HIV and SIV. Curr Opin HIV AIDS (2011) 6:221-7. doi:10.1097/COH.0b013e32834577b3

95. He Y, Li J, Zheng Y, Luo Y, Zhou H, Yao Y, et al. A randomized case-control study of dynamic changes in peripheral blood Th17/Treg cell balance and interleukin-17 levels in highly active antiretroviral-treated HIV type 1/ AIDS patients. AIDS Res Hum Retroviruses (2012) 28:339-45. doi:10.1089/ AID.2011.0140

96. Bixler SL, Mattapallil JJ. Loss and dysregulation of Th17 cells during HIV infection. Clin Dev Immunol (2013) 2013:852418. doi:10.1155/2013/ 852418

97. Blaschitz C, Raffatellu M. Th17 cytokines and the gut mucosal barrier. J Clin Immunol (2010) 30:196-203. doi:10.1007/s10875-010-9368-7

98. Li D, Chen J, Jia M, Hong K, Ruan Y, Liang H, et al. Loss of balance between $\mathrm{T}$ helper type 17 and regulatory $\mathrm{T}$ cells in chronic human immunodeficiency virus infection. Clin Exp Immunol (2011) 165:363-71. doi:10.1111/j.1365-2249.2011.04435.x

99. Valverde-Villegas JM, Matte MC, de Medeiros RM, Chies JA. New insights about Treg and Th17 cells in HIV infection and disease progression. J Immunol Res (2015) 2015:647916. doi:10.1155/2015/647916

100. Eggena MP, Barugahare B, Jones N, Okello M, Mutalya S, Kityo C, et al. Depletion of regulatory T cells in HIV infection is associated with immune activation. J Immunol (2005) 174:4407-14. doi:10.4049/jimmunol.174.7.4407

101. Baker CA, Clark R, Ventura F, Jones NG, Guzman D, Bangsberg DR, et al. Peripheral CD4 loss of regulatory $\mathrm{T}$ cells is associated with persistent viraemia in chronic HIV infection. Clin Exp Immunol (2007) 147:533-9. doi:10.1111/j.1365-2249.2006.03319.x

102. Chase AJ, Sedaghat AR, German JR, Gama L, Zink MC, Clements JE, et al. Severe depletion of CD4+ CD25+ regulatory T cells from the intestinal lamina propria but not peripheral blood or lymph nodes during acute simian immunodeficiency virus infection. J Virol (2007) 81:12748-57. doi:10.1128/ JVI.00841-07

103. Favre D, Mold J, Hunt PW, Kanwar B, Loke P, Seu L, et al. Tryptophan catabolism by indoleamine 2,3-dioxygenase 1 alters the balance of TH17 to regulatory T cells in HIV disease. Sci Transl Med (2010) 2:32ra36. doi:10.1126/ scitranslmed. 3000632

104. Pallikkuth S, Micci L, Ende ZS, Iriele RI, Cervasi B, Lawson B, et al. Maintenance of intestinal Th17 cells and reduced microbial translocation in SIV-infected rhesus macaques treated with interleukin (IL)-21. PLoS Pathog (2013) 9:e1003471. doi:10.1371/journal.ppat.1003471

105. Pallikkuth S, Pahwa S. Interleukin-21 and T follicular helper cells in HIV infection: research focus and future perspectives. Immunol Res (2013) 57:279-91. doi:10.1007/s12026-013-8457-0

106. Girard A, Vergnon D, Depince-Berger AE, Roblin X, Lutch F, Lambert C, et al. A high rate of beta7+ gut homing lymphocytes in HIV infected immunological non responders is associated with poor CD4 T cell recovery during suppressive HAART. J Acquir Immune Defic Syndr (2016). doi:10.1097/ QAI.0000000000000943

107. Kistler JO, Arirachakaran P, Poovorawan Y, Dahlen G, Wade WG. The oral microbiome in human immunodeficiency virus (HIV)-positive individuals. J Med Microbiol (2015) 64:1094-101. doi:10.1099/jmm.0.000128

108. d'Ettorre G, Ceccarelli G, Giustini N, Serafino S, Calantone N, De Girolamo G, et al. Probiotics reduce inflammation in antiretroviral treated, HIV-infected individuals: results of the "probio-HIV" clinical trial. PLoS One (2015) 10:e0137200. doi:10.1371/journal.pone.0137200

109. Pandiyan P, Zheng L, Lenardo MJ. The molecular mechanisms of regulatory T cell immunosuppression. Front Immunol (2011) 2:60. doi:10.3389/ fimmu.2011.00060

110. Pandiyan P, Zheng L, Ishihara S, Reed J, Lenardo MJ. CD4(+)CD25(+) Foxp3(+) regulatory T cells induce cytokine deprivation-mediated apoptosis of effector CD4(+) T cells. Nat Immunol (2007) 8:1353-62. doi:10.1038/ ni1536
111. Josefowicz SZ, Lu LF, Rudensky AY. Regulatory T cells: mechanisms of differentiation and function. Annu Rev Immunol (2012) 30:531-64. doi:10.1146/ annurev.immunol.25.022106.141623

112. Kosmaczewska A. Low-dose interleukin-2 therapy: a driver of an imbalance between immune tolerance and autoimmunity. Int J Mol Sci (2014) 15:18574-92. doi:10.3390/ijms151018574

113. Singer BD, King LS, D’Alessio FR. Regulatory T cells as immunotherapy. Front Immunol (2014) 5:46. doi:10.3389/fimmu.2014.00046

114. Fazekas de St Groth B, Landay AL. Regulatory T cells in HIV infection: pathogenic or protective participants in the immune response? AIDS (2008) 22:671-83. doi:10.1097/QAD.0b013e3282f466da

115. Loke P, Favre D, Hunt PW, Leung JM, Kanwar B, Martin JN, et al. Correlating cellular and molecular signatures of mucosal immunity that distinguish HIV controllers from noncontrollers. Blood (2010) 115:e20-32. doi:10.1182/ blood-2009-12-257451

116. Chevalier MF, Weiss L. The split personality of regulatory T cells in HIV infection. Blood (2013) 121:29-37. doi:10.1182/blood-2012-07-409755

117. Moreno-Fernandez ME, Rueda CM, Rusie LK, Chougnet CA. Regulatory $\mathrm{T}$ cells control HIV replication in activated $\mathrm{T}$ cells through a cAMP-dependent mechanism. Blood (2011) 117:5372-80. doi:10.1182/blood-2010-12323162

118. Elahi S, Dinges WL, Lejarcegui N, Laing KJ, Collier AC, Koelle DM, et al. Protective HIV-specific CD8+ T cells evade Treg cell suppression. Nat Med (2011) 17:989-95. doi:10.1038/nm.2422

119. Kinter AL, Hennessey M, Bell A, Kern S, Lin Y, Daucher M, et al. CD25(+) $\mathrm{CD} 4(+)$ regulatory $\mathrm{T}$ cells from the peripheral blood of asymptomatic HIV-infected individuals regulate $\mathrm{CD} 4(+)$ and $\mathrm{CD} 8(+)$ HIV-specific T cell immune responses in vitro and are associated with favorable clinical markers of disease status. J Exp Med (2004) 200:331-43. doi:10.1084/jem. 20032069

120. Weiss L, Donkova-Petrini V, Caccavelli L, Balbo M, Carbonneil C, Levy Y. Human immunodeficiency virus-driven expansion of $\mathrm{CD} 4+\mathrm{CD} 25+$ regulatory Tcells, which suppress HIV-specific CD4 T-cell responses in HIV-infected patients. Blood (2004) 104:3249-56. doi:10.1182/blood-2004-01-0365

121. Mozos A, Garrido M, Carreras J, Plana M, Diaz A, Alos L, et al. Redistribution of FOXP3-positive regulatory $\mathrm{T}$ cells from lymphoid tissues to peripheral blood in HIV-infected patients. J Acquir Immune Defic Syndr (2007) 46:529-37. doi:10.1097/QAI.0b013e31815b69ae

122. Tenorio AR, Martinson J, Pollard D, Baum L, Landay A. The relationship of T-regulatory cell subsets to disease stage, immune activation, and pathogen-specific immunity in HIV infection. J Acquir Immune Defic Syndr (2008) 48:577-80. doi:10.1097/QAI.0b013e31817bbea5

123. Jiao Y, Fu J, Xing S, Fu B, Zhang Z, Shi M, et al. The decrease of regulatory $\mathrm{T}$ cells correlates with excessive activation and apoptosis of CD8+ T cells in HIV-1-infected typical progressors, but not in long-term non-progressors. Immunology (2009) 128:e366-75. doi:10.1111/j.1365-2567.2008.02978.x

124. Terzieva V, Popova D, Kicheva M, Todorova Y, Markova R, Martinova F, et al. Correlation between the degree of immune activation, production of IL-2 and FOXP3 expression in CD4+CD25+ T regulatory cells in HIV-1 infected persons under HAART. Int Immunopharmacol (2009) 9:831-6. doi:10.1016/j. intimp.2009.03.009

125. Owen RE, Heitman JW, Hirschkorn DF, Lanteri MC, Biswas HH, Martin JN, et al. HIV+ elite controllers have low HIV-specific T-cell activation yet maintain strong, polyfunctional T-cell responses. AIDS (2010) 24:1095-105. doi:10.1097/QAD.0b013e3283377ale

126. Rodriguez B, Bazdar DA, Funderburg N, Asaad R, Luciano AA, Yadavalli G, et al. Frequencies of FoxP3+ naive T cells are related to both viral load and naive T cell proliferation responses in HIV disease. J Leukoc Biol (2011) 90:621-8. doi:10.1189/jlb.1210661

127. Angin M, Kwon DS, Streeck H, Wen F, King M, Rezai A, et al. Preserved function of regulatory T cells in chronic HIV-1 infection despite decreased numbers in blood and tissue. J Infect Dis (2012) 205:1495-500. doi:10.1093/ infdis/jis 236

128. Gaardbo JC, Ronit A, Hartling HJ, Gjerdrum LM, Springborg K, Ralfkiaer E, et al. Immunoregulatory $\mathrm{T}$ cells may be involved in preserving $\mathrm{CD} 4 \mathrm{~T}$ cell counts in HIV-infected long-term nonprogressors and controllers. J Acquir Immune Defic Syndr (2014) 65:10-8. doi:10.1097/QAI.0b013e3182a7c932 
129. Wang X, Xu H, Shen C, Alvarez X, Liu D, Pahar B, et al. Profound loss of intestinal Tregs in acutely SIV-infected neonatal macaques. J Leukoc Biol (2015) 97:391-400. doi:10.1189/jlb.4A0514-266RR

130. Epple HJ, Loddenkemper C, Kunkel D, Troger H, Maul J, Moos V, et al. Mucosal but not peripheral FOXP3+ regulatory T cells are highly increased in untreated HIV infection and normalize after suppressive HAART. Blood (2006) 108:3072-8. doi:10.1182/blood-2006-04-016923

131. Cao W, Jamieson BD, Hultin LE, Hultin PM, Detels R. Regulatory T cell expansion and immune activation during untreated HIV type 1 infection are associated with disease progression. AIDS Res Hum Retroviruses (2009) 25:183-91. doi:10.1089/aid.2008.0140

132. Piconi S, Trabattoni D, Gori A, Parisotto S, Magni C, Meraviglia P, et al. Immune activation, apoptosis, and Treg activity are associated with persistently reduced CD4+ T-cell counts during antiretroviral therapy. AIDS (2010) 24:1991-2000. doi:10.1097/QAD.0b013e32833c93ce

133. Zeitz M, Ullrich R, Schneider T, Schieferdecker HL, Riecken EO. Cell differentiation and proliferation in the gastrointestinal tract with respect to the local immune system. Ann N Y Acad Sci (1994) 733:75-86. doi:10.111 1/j.1749-6632.1994.tb17258.x

134. Shaw JM, Hunt PW, Critchfield JW, McConnell DH, Garcia JC, Pollard RB, et al. Increased frequency of regulatory $\mathrm{T}$ cells accompanies increased immune activation in rectal mucosae of HIV-positive noncontrollers. J Virol (2011) 85:11422-34. doi:10.1128/JVI.05608-11

135. Allers K, Loddenkemper C, Hofmann J, Unbehaun A, Kunkel D, Moos V, et al. Gut mucosal FOXP3+ regulatory CD4+ T cells and Nonregulatory CD4+ $\mathrm{T}$ cells are differentially affected by simian immunodeficiency virus infection in rhesus macaques. J Virol (2010) 84:3259-69. doi:10.1128/ JVI.01715-09

136. Mendez-Lagares G, Pozo-Balado MM, Genebat M, Garcia Perganeda A, Leal M, Pacheco YM. Severe immune dysregulation affects CD4(+) CD25(hi)FoxP3(+) regulatory $\mathrm{T}$ cells in HIV-infected patients with low-level CD4 T-cell repopulation despite suppressive highly active antiretroviral therapy. J Infect Dis (2012) 205:1501-9. doi:10.1093/ infdis/jis 230

137. Khowawisetsut L, Pattanapanyasat K, Onlamoon N, Mayne AE, Little DM, Villinger F, et al. Relationships between IL-17(+) subsets, Tregs and pDCs that distinguish among SIV infected elite controllers, low, medium and high viral load rhesus macaques. PLoS One (2013) 8:e61264. doi:10.1371/journal. pone.0061264

138. Falivene J, Ghiglione Y, Laufer N, Eugenia Socias M, Pia Holgado M, Julia Ruiz M, et al. Th17 and Th17/Treg ratio at early HIV infection associate with protective HIV-specific CD8(+) T-cell responses and disease progression. Sci Rep (2015) 5:11511. doi:10.1038/srep11511

139. Saison J, Maucort Boulch D, Chidiac C, Demaret J, Malcus C, Cotte L, et al. Increased regulatory $\mathrm{T}$-cell percentage contributes to poor CD4(+) lymphocytes recovery: a 2-year prospective study after introduction of antiretroviral therapy. Open Forum Infect Dis (2015) 2:ofv063. doi:10.1093/ofid/ ofv063

140. Chevalier MF, Petitjean G, Dunyach-Remy C, Didier C, Girard PM, Manea ME, et al. The Th17/Treg ratio, IL-1RA and sCD14 levels in primary HIV infection predict the T-cell activation set point in the absence of systemic microbial translocation. PLoS Pathog (2013) 9:e1003453. doi:10.1371/ journal.ppat.1003453

141. Micci L, Alvarez X, Iriele RI, Ortiz AM, Ryan ES, McGary CS, et al. CD4 depletion in SIV-infected macaques results in macrophage and microglia infection with rapid turnover of infected cells. PLoS Pathog (2014) 10:e1004467. doi:10.1371/journal.ppat.1004467

142. Micci L, Ryan ES, Fromentin R, Bosinger SE, Harper JL, He T, et al. Interleukin-21 combined with ART reduces inflammation and viral reservoir in SIV-infected macaques. J Clin Invest (2015) 125(12):4497-513. doi:10.1172/JCI81400

143. Mercer F, Khaitan A, Kozhaya L, Aberg JA, Unutmaz D. Differentiation of IL17 -producing effector and regulatory human $\mathrm{T}$ cells from lineage-committed naive precursors. J Immunol (2014) 193:1047-54. doi:10.4049/jimmunol. 1302936

144. Miller E, Bhardwaj N. Dendritic cell dysregulation during HIV-1 infection. Immunol Rev (2013) 254:170-89. doi:10.1111/imr.12082

145. Bhaskaran N, Quigley C, Weinberg A, Huang A, Popkin D, Pandiyan P. Transforming growth factor-betal sustains the survival of Foxp3 regulatory cells during late phase of oropharyngeal candidiasis infection. Mucosal Immunol (2015). doi:10.1038/mi.2015.115

146. Yurchenko E, Shio MT, Huang TC, Da Silva Martins M, Szyf M, Levings MK, et al. Inflammation-driven reprogramming of CD4+ Foxp3+ regulatory $\mathrm{T}$ cells into pathogenic Th1/Th17 T effectors is abrogated by mTOR inhibition in vivo. PLoS One (2012) 7:e35572. doi:10.1371/journal.pone.0035572

147. Pesenacker AM, Bending D, Ursu S, Wu Q, Nistala K, Wedderburn LR. CD161 defines the subset of FoxP3 + T cells capable of producing proinflammatory cytokines. Blood (2013) 121:2647-58. doi:10.1182/blood-2012-08443473

148. Pesenacker AM, Broady R, Levings MK. Control of tissue-localized immune responses by human regulatory T cells. Eur J Immunol (2015) 45:333-43. doi:10.1002/eji.201344205

149. Pandiyan $\mathrm{P}, \mathrm{Zhu}$ J. Origin and functions of pro-inflammatory cytokine producing Foxp3(+) regulatory T cells. Cytokine (2015) 76:13-24. doi:10.1016/j. cyto.2015.07.005

150. Bhaskaran N, Cohen S, Zhang Y, Weinberg A, Pandiyan P. TLR-2 signaling promotes IL-17A production in CD4+CD25+Foxp3+ regulatory cells during oropharyngeal candidiasis. Pathogens (2015) 4:90-110. doi:10.3390/ pathogens 4010090

151. Tan DB, Lim A, Yong YK, Ponnampalavanar S, Omar S, Kamarulzaman A, et al. TLR2-induced cytokine responses may characterize HIV-infected patients experiencing mycobacterial immune restoration disease. AIDS (2011) 25:1455-60. doi:10.1097/QAD.0b013e328348fb18

152. Thayil SM, Ho YC, Bollinger RC, Blankson JN, Siliciano RF, Karakousis PC, et al. Mycobacterium tuberculosis complex enhances susceptibility of CD4 T cells to HIV through a TLR2-mediated pathway. PLoS One (2012) 7:e41093. doi:10.1371/journal.pone.0041093

153. Rodriguez ME, Loyd CM, Ding X, Karim AF, McDonald DJ, Canaday DH, et al. Mycobacterial phosphatidylinositol mannoside 6 (PIM6) up-regulates TCR-triggered HIV-1 replication in CD4+ T cells. PLoS One (2013) 8:e80938. doi:10.1371/journal.pone.0080938

154. Vernon LT, Demko CA, Babineau DC, Wang X, Toossi Z, Weinberg A, et al. Effect of Nadir CD4+ T cell count on clinical measures of periodontal disease in HIV+ adults before and during immune reconstitution on HAART. PLoS One (2013) 8:e76986. doi:10.1371/journal.pone.0076986

155. Ayash-Rashkovsky M, Bentwich Z, Borkow G. TLR9 expression is related to immune activation but is impaired in individuals with chronic immune activation. Int J Biochem Cell Biol (2005) 37:2380-94. doi:10.1016/j.biocel.2005. 05.012

156. Jiang W, Lederman MM, Hunt P, Sieg SF, Haley K, Rodriguez B, et al. Plasma levels of bacterial DNA correlate with immune activation and the magnitude of immune restoration in persons with antiretroviral-treated HIV infection. J Infect Dis (2009) 199:1177-85. doi:10.1086/597476

157. Fergusson JR, Smith KE, Fleming VM, Rajoriya N, Newell EW, Simmons R, et al. CD161 defines a transcriptional and functional phenotype across distinct human T cell lineages. Cell Rep (2014) 9:1075-88. doi:10.1016/j. celrep.2014.09.045

158. Gonzalez Y, Herrera MT, Juarez E, Salazar-Lezama MA, Bobadilla K, Torres M. CD161 expression defines a Th1/Th17 polyfunctional subset of resident memory T lymphocytes in bronchoalveolar cells. PLoS One (2015) 10:e0123591. doi:10.1371/journal.pone.0123591

159. Basdeo SA, Moran B, Cluxton D, Canavan M, McCormick J, Connolly M, et al. Polyfunctional, pathogenic CD161+ Th17 lineage cells are resistant to regulatory $\mathrm{T}$ cell-mediated suppression in the context of autoimmunity. J Immunol (2015) 195:528-40. doi:10.4049/jimmunol.1402990

160. Chevalier MF, Didier C, Petitjean G, Karmochkine M, Girard PM, Barre-Sinoussi $\mathrm{F}$, et al. Phenotype alterations in regulatory T-cell subsets in primary HIV infection and identification of Tr1-like cells as the main interleukin 10-producing CD4+ T cells. J Infect Dis (2015) 211:769-79. doi:10.1093/infdis/jiu549

161. Maina EK, Abana CZ, Bukusi EA, Sedegah M, Lartey M, Ampofo WK. Plasma concentrations of transforming growth factor beta 1 in non-progressive HIV-1 infection correlates with markers of disease progression. Cytokine (2016) 81:109-16. doi:10.1016/j.cyto.2016.02.009

162. Hernandez JC, St Laurent G III, Urcuqui-Inchima S. HIV-1-exposed seronegative individuals show alteration in TLR expression and pro-inflammatory cytokine production ex vivo: an innate immune quiescence status? Immunol Res (2016) 64:280-90. doi:10.1007/s12026-015-8748-8 
163. Rubtsov YP, Niec RE, Josefowicz S, Li L, Darce J, Mathis D, et al. Stability of the regulatory T cell lineage in vivo. Science (2010) 329:1667-71. doi:10.1126/ science.1191996

164. Chaudhry A, Rudensky AY. Control of inflammation by integration of environmental cues by regulatory T cells. J Clin Invest (2013) 123:939-44. doi:10.1172/JCI57175

165. Klatt NR, Silvestri G. CD4+ T cells and HIV: a paradoxical Pas de Deux. Sci Transl Med (2012) 4:123s124. doi:10.1126/scitranslmed.3003862

166. Levy Y, Thiebaut R, Gougeon ML, Molina JM, Weiss L, Girard PM, et al. Effect of intermittent interleukin-2 therapy on CD4+ T-cell counts following antiretroviral cessation in patients with HIV. AIDS (2012) 26:711-20. doi:10.1097/QAD.0b013e3283519214

167. Porter BO, Anthony KB, Shen J, Hahn B, Keh CE, Maldarelli F, et al. Inferiority of IL-2 alone versus IL-2 with HAART in maintaining CD4 T cell counts during HAART interruption: a randomized controlled trial. AIDS (2009) 23:203-12. doi:10.1097/QAD.0b013e32831cc114

168. Porter BO, Ouedraogo GL, Hodge JN, Smith MA, Pau A, Roby G, et al. d-Dimer and CRP levels are elevated prior to antiretroviral treatment in patients who develop IRIS. Clin Immunol (2010) 136:42-50. doi:10.1016/j. clim.2010.02.010

169. Sereti I, Dunham RM, Spritzler J, Aga E, Proschan MA, Medvik K, et al. IL-7 administration drives T cell-cycle entry and expansion in HIV-1 infection. Blood (2009) 113:6304-14. doi:10.1182/ blood-2008-10-186601

170. Levy Y, Sereti I, Tambussi G, Routy JP, Lelievre JD, Delfraissy JF, et al. Effects of recombinant human interleukin 7 on T-cell recovery and thymic output in HIV-infected patients receiving antiretroviral therapy: results of a phase I/
IIa randomized, placebo-controlled, multicenter study. Clin Infect Dis (2012) 55:291-300. doi:10.1093/cid/cis383

171. Pandiyan P, Lenardo MJ. The control of CD4+CD25+Foxp3+ regulatory T cell survival. Biol Direct (2008) 3:6. doi:10.1186/1745-6150-3-6

172. Levy DN, Aldrovandi GM, Kutsch O, Shaw GM. Dynamics of HIV-1 recombination in its natural target cells. Proc Natl Acad Sci U S A (2004) 101:4204-9. doi:10.1073/pnas.0306764101

173. Freed EO, Martin MA. The role of human immunodeficiency virus type 1 envelope glycoproteins in virus infection. J Biol Chem (1995) 270:23883-6. doi:10.1074/jbc.270.41.23883

174. Reyes-Rodriguez AL, Reuter MA, McDonald D. Dendritic cells enhance HIV infection of memory CD4(+) T cells in human lymphoid tissues. AIDS Res Hum Retroviruses (2016) 32:203-10. doi:10.1089/AID. 2015.0235

Conflict of Interest Statement: The authors declare that the research was conducted in the absence of any commercial or financial relationships that could be construed as a potential conflict of interest.

Copyright (C) 2016 Pandiyan, Younes, Ribeiro, Talla, McDonald, Bhaskaran, Levine, Weinberg and Sekaly. This is an open-access article distributed under the terms of the Creative Commons Attribution License (CC BY). The use, distribution or reproduction in other forums is permitted, provided the original author(s) or licensor are credited and that the original publication in this journal is cited, in accordance with accepted academic practice. No use, distribution or reproduction is permitted which does not comply with these terms. 